\title{
Maternal Supply of Both Arachidonic and Docosahexaenoic Acids Is Required for Optimal Neurodevelopment
}

\author{
Sanjay Basak $^{1}\left(\mathbb{D}\right.$, Rahul Mallick $^{2}(\mathbb{D})$, Antara Banerjee ${ }^{3}$, Surajit Pathak ${ }^{3} \mathbb{D}$ and Asim K. Duttaroy ${ }^{4, *(\mathbb{D})}$ \\ 1 Molecular Biology Division, ICMR-National Institute of Nutrition, Indian Council of Medical Research, \\ Hyderabad 500 007, India; sba_bioc@yahoo.com \\ 2 A.I. Virtanen Institute for Molecular Sciences, University of Eastern Finland, 70210 Kuopio, Finland; \\ rahul.mallick@uef.fi \\ 3 Department of Medical Biotechnology, Faculty of Allied Health Sciences, Chettinad Academy of Research and \\ Education (CARE), Chettinad Hospital and Research Institute (CHRI), Kelambakkam, Chennai 603 103, India; \\ antara.banerjee27@gmail.com (A.B.); surajit.pathak@gmail.com (S.P.) \\ 4 Department of Nutrition, Institute of Basic Medical Sciences, Faculty of Medicine, University of Oslo, \\ 0317 Oslo, Norway \\ * Correspondence: a.k.duttaroy@medisin.uio.no; Tel.: +47-22-82-15-47
}

Citation: Basak, S.; Mallick, R.; Banerjee, A.; Pathak, S.; Duttaroy, A.K. Maternal Supply of Both Arachidonic and Docosahexaenoic Acids Is Required for Optimal Neurodevelopment. Nutrients 2021, 13, 2061. https://doi.org/ 10.3390/nu13062061

Academic Editor: Andrew J. Sinclair

Received: 25 April 2021

Accepted: 14 June 2021

Published: 16 June 2021

Publisher's Note: MDPI stays neutral with regard to jurisdictional claims in published maps and institutional affiliations.

Copyright: (c) 2021 by the authors. Licensee MDPI, Basel, Switzerland. This article is an open access article distributed under the terms and conditions of the Creative Commons Attribution (CC BY) license (https:// creativecommons.org/licenses/by/ $4.0 /)$.

\begin{abstract}
During the last trimester of gestation and for the first 18 months after birth, both docosahexaenoic acid,22:6n-3 (DHA) and arachidonic acid,20:4n-6 (ARA) are preferentially deposited within the cerebral cortex at a rapid rate. Although the structural and functional roles of DHA in brain development are well investigated, similar roles of ARA are not well documented. The mode of action of these two fatty acids and their derivatives at different structural-functional roles and their levels in the gene expression and signaling pathways of the brain have been continuously emanating. In addition to DHA, the importance of ARA has been much discussed in recent years for fetal and postnatal brain development and the maternal supply of ARA and DHA. These fatty acids are also involved in various brain developmental processes; however, their mechanistic cross talks are not clearly known yet. This review describes the importance of ARA, in addition to DHA, in supporting the optimal brain development and growth and functional roles in the brain.
\end{abstract}

Keywords: arachidonic acid,20:4n-6; brain; docosahexaenoic acid,22:6n-3; fetus; maternal diet; cognitive; infants; neurodevelopment; neurogenesis

\section{Introduction}

The neurodevelopmental process involves a complex interplay between nutrients, genes, and environmental factors that result in the optimal growth, development, and maturation of the brain. The development of the brain in utero critically depends on the maternal supply of several components for its well-regulated structural-developmental process, characterized by specifically defined developmental periods, growth, a cellular signaling system, and maturation. During the brain growth spurt, neurodevelopment is particularly vulnerable to nutritional deficiencies [1].

The long-chain polyunsaturated fatty acids (LCPUFAs), docosahexaenoic acid,22:6n-3 (DHA), and arachidonic acid,20:4n-6 (ARA) are important nutrients required for fetal brain growth and development. The accumulation of DHA and ARA in the fetal brain predominantly occurs in the third trimester of a human pregnancy. The de novo synthesis of these LCPUFAs seems low in a growing fetus and placenta [2]; the maternal intake of these fatty acids contributes a significant share for brain development. Maternal DHA and ARA are accumulated rapidly within the cerebral cortex during the last trimester of pregnancy and postnatal 18 months [2-4]. The dietary balance of DHA and ARA intake and their interactions are thought to be important for the development and function of the brain. Several experimental studies suggested a crucial involvement of these two fatty acids in neural membrane formation and various roles of their metabolites, production of 
eicosanoids, and their influence on depression- and anxiety-related behaviors. Moreover, multiple trials have found that higher plasma or erythrocyte DHA levels positively correlate with infant neurocognitive outcomes [5-10].

High levels of DHA in the brain are achieved during early life and are maintained throughout life. DHA accretion to the brain continues into childhood, and the incorporation of DHA is still high despite its reduced accumulation rate. The preferential transfer of maternal DHA and ARA by the placenta to fetal circulation and its mechanisms are reviewed extensively [11,12]. LCPUFA content in human milk also regulate the amount of DHA and ARA transferred to the infant during breastfeeding [13]. However, this phenomenon may depend on an optimal maternal dietary intake of DHA from the supplement or marine fish [14], whereas ARA levels are usually maintained due to high n-6/n-3 ratios in the diet.

In the central nervous system (CNS), the proportion of DHA with other membrane fatty acids increases as the brain size increases. The increase in the proportion of these fatty acids continues for the second year of life. DHA has significant neurobiochemical roles in ion channel and receptor functions, the release of neurotransmitters, synaptic plasticity, and gene expression in the neurons. Both DHA and ARA of synaptic membrane phospholipids are released as free fatty acids (FFAs) by activated phospholipase $\mathrm{A}_{2}\left(\mathrm{PLA}_{2}\right)$ and are converted to different bioactive metabolites. These liberated fatty acids and the metabolites play critical roles during ischemia seizure activity, inflammation, and other types of brain disorders. Figure 1 describes the putative roles of DHA in neural membranes.

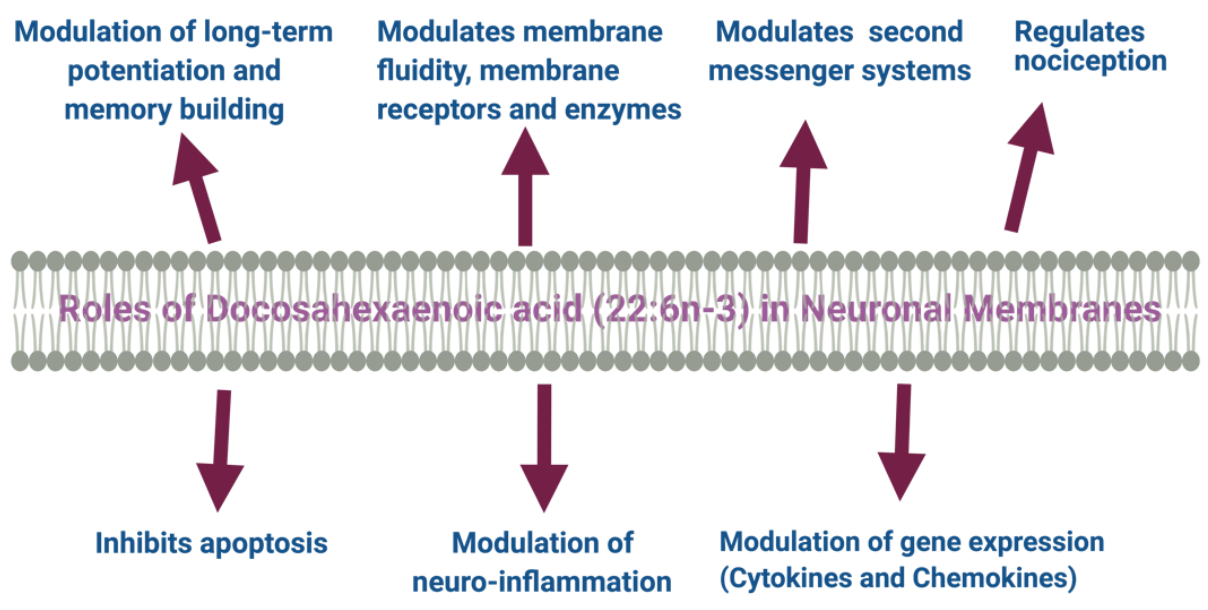

Figure 1. DHA modulates several aspects of structural and functional activities of neuronal membrane.

Maternal n-3 PUFA deficiency during pregnancy was associated with impaired brain development in offspring [15] and defective neuroblast migration [16]. The deficiency of n-3 LCPUFAs during development causes hypomyelination in the brain, resulting in mood and anxiety disorders $[17,18]$. Consuming a diet containing a high amount of n-3 fatty acids during pregnancy protected infants against the detrimental effects of maternal stress [19].

The essentiality of DHA is well recognized in childhood and adult life, as its deficiency causes cognitive decline and other psychiatric disorders [20]. Plasma DHA levels are inversely correlated with depressive symptoms in infants and adolescents with bipolar disorder [21]. Human breast milk containing higher n-3 and n-6 LCPUFAs was associated with decreased infant despair and distress [22]. The impact of n-3 PUFAs in human milk in influencing infant mood or anxiety is still not clearly established, since cortisol levels in milk are also associated with infant temperament [23]. Moreover, the variation in the fatty acid composition of mothers' milk may play an essential role in the outcome of offspring's mental status and overall health.

Although n-3 LCPUFAs supplementation is beneficial in preventing and treating major depression, bipolar disorder, and anxiety disorders in adults [24,25], much less is known about how the imbalance of these LCPUFA levels impact the mood and behavior of 
infants. Studies in experimental models suggested that early exposure to $n-3$ fatty acids had a lasting effect on temperament and behavioral phenotypes of offspring [26]. Interventional studies in adults also showed an association between the n-3 PUFA status with improved mood and mental health $[17,26]$.

Though precise molecular mechanisms are not well defined, DHA and its bioactive derivatives play various essential structural and functional roles in the brain [12,27,28]. High DHA levels in the phospholipids of synaptic membranes provide membrane flexibility and improve the efficiency of protein-protein interaction necessary for signal transduction [27]. Different aspects of metabolism, and the structure-function of the brain depend on optimum ARA and DHA levels and interactions between their metabolites [29]. Cognitive benefits from supplementation of combined ARA and DHA in early life have also been observed through early and middle childhood [30,31]. Furthermore, several human brain diseases, such as Alzheimer's and bipolar disorders, involve disturbed n-3 and n-6 LCPUFA uptake and metabolism. Therefore, understanding the dynamics of the maternal supply of DHA and ARA to the developing brain may be important for managing brain disorders. An additional neuroprotective mechanism may involve bioactive molecules derived from DHA and ARA, which are also involved in several cellular neuronal biochemical processes. These bioactive derivatives modify the functions of several genes in the brain by acting as ligands for transcription factors involved in critical brain functions, including signal transduction and synaptic plasticity.

A literature search was performed on the PubMed database by using search terms such as DHA, ARA, brain development, infant, fetal, breastfeeding nutrients deficiency, DHA and ARA supplementation. All types of articles related to human and mechanistic studies on models were included for evaluation. The articles for which full text was not available or not reported in English were excluded. The articles retrieved in the first round of searches identified additional references by a manual search among the cited references. This review describes the latest development of the interplay of DHA and ARA transfer and their impacts on brain development, their complementarity, the structure-function relationship, and their mechanisms of action in the brain. Moreover, the evidence of the essentiality of ARA in brain development is summarized.

\section{Maternal Delivery of DHA and ARA to the Developing Brain}

Both DHA and ARA are major components of the brain. DHA comprises $10-20 \%$ of the total fatty acid composition in the brain, whereas $9 \%$ is present in the form of ARA [32]. During the third trimester of pregnancy, these LCPUFAs preferentially accumulate in the fetus and reach higher fetal/neonatal blood levels than those in the mother [33]. Both DHA and ARA are deposited in large amounts relative to the accretion rates of other fatty acids in the fetal brain during a maximum brain growth spurt, which occurs from the last trimester in utero and continues through the breastfed postnatal life $[4,34-36]$. The development of the brain is critically dependent on the adequate maternal supply of LCPUFAs in this period, since their synthesis from the parent EFAs is insufficient to meet the high requirement $[4,37]$. The lower fetal status of both DHA and ARA is associated with neurological development [38]. Consequently, ample fetal and neonatal LCPUFA supply via transplacental transport and human milk is critically important, implying that maternal LCPUFA status should be adequate.

Maternal dietary intakes of fatty acids influence the fatty acid composition of breast milk and plasma levels of lactating women and their infants [39]. DHA incorporation in the neuronal membrane in early fetal life solely depends on placental transfer [11], breastfeeding, and the endogenous synthesis of DHA [40-42]. However, DHA accretion in the CNS depends on the dietary provision of DHA, i.e., on the duration and concentration of DHA supplementation. A similar nutritional dependency is absent for ARA accretion in the brain, i.e., the dosage and duration of postnatal ARA supplementation do not affect ARA accretion in the CNS [43]. 
A robust linear relationship between maternal DHA level and umbilical cord blood phospholipid was reported [44]. Both ARA and DHA also have a role in the early placentation process, in addition to their roles in fetal neurodevelopment and in the postnatal lactation period [45-47]. The high-affinity placental plasma membrane, fatty acid-binding protein (p-FABPpm), is involved in the preferential supply of both maternal DHA and ARA to the fetus $[12,41,48]$. Since the rapid deposition of these LCPUFAs into the brain occurs during the last trimester of pregnancy and subsequently in lactation, the maternal status must be maintained well during the critical time of brain development. The dietary intake and maternal stores of DHA are the determinants of infant blood DHA concentrations at birth [49]. Blood LCPUFAs in breast-fed infants remain higher than those in maternal circulation postnatally [50,51]. The blood levels of PUFAs of infants are higher than those in the maternal circulation postnatally during the breastfeeding period. The preferential postnatal deposition of LCPUFAs in the infant's brain is mediated via breastmilk. The dietary supplementation of DHA to pregnant and nursing mothers dose-dependently increases the DHA level in breast milk, which causes higher tissue accretion of DHA in breastfed infants with improved outcomes of mental performance [52-54]. The erythrocyte DHA status of breastfed infants is correlated with the maternal DHA status of erythrocytes during lactation; however, no such association was observed for ARA [13]. Human breast milk levels of DHA and ARA are relatively stable throughout the lactation [55]. The worldwide mean concentration of DHA is $0.3 \pm 0.2 \%$, and that of ARA is $0.5 \pm 0.1 \%$ in breast milk [56]. Typically, human breast milk has 1.5- to 2-fold more ARA than DHA, though the breast milk's DHA content can be higher than ARA in populations with high marine fish consumption. It has been shown that the DHA level in breast milk is directly related to the DHA content of the maternal diet [57]. Still, it is unknown whether metabolic or dietary mechanisms explain the lower variability in breast milk ARA. Breast milk ARA was not affected in lactating mothers allocated to consume increasing doses of DHA [57]. Two recent studies confirmed the different regulation of ARA and DHA in breast milk, indicating that ARA is affected by the genetic pattern in the FADS-gene cluster [58] and is less sensitive than DHA to dietary supplementation [59]. The essentiality of ARA in infant nutrition is supported by the observation of the potentially adverse effects in preterm infants of consuming a marine-oil-containing formula [60]. Dietary ARA has roles in growth, neuronal development, and cognitive function in infants. Both ARA and DHA are necessary for fetal development, and a deficiency in one may compromise growth [61]. It has been shown that growth deficiency induced by fish oil supplementation is related to a reduced ARA availability due to the excess of DHA [62]. Western diets usually have a much higher ratio of n-6/n-3 fatty acids [63]. Therefore, it has been proposed that supplementation during gestation should be based on intake of n-3 fatty acids.

Children's intelligence quotient (IQ) was increased by 0.8 to 1.8 points when their mothers consumed DHA from pregnancy to the lactation period and beyond $[64,65]$. The mean levels of DHA and ARA in breast milk are found at $0.37 \%$ and $0.55 \%$ of total fatty acids across the globe, respectively. Prospective observational studies suggested that breastfed infants had a significant neurocognitive advantage compared with formula-fed infants $[5,66,67]$, possibly due to the higher incorporation of DHA and ARA in breast milk relative to formula milk. The association between breastfeeding and child IQ concerning FADS2 genetic profile, specifically in SNP rs174575b, was observed [68]. Breastfed infants with rs174575 C-dominant carriers achieved higher scores on standardized IQ tests than non-breastfed C-carrier infants. However, observational data are confounded by the heterogeneous composition of breast milk, and environmental factors that influence the infant's mental development.

Based on established guidelines, it is emphasized that maternal dietary DHA requirements should be increased during pregnancy and lactation. Precisely, a minimum of $200 \mathrm{mg}$ of DHA per day is recommended during these periods [69]. In both full-term and preterm populations, the evidence is compelling that breastfeeding is vital for an infant's neurodevelopment. 


\section{The Fatty Acid Uptake System of the Brain}

The de novo synthesis of DHA in the brain is almost non-existent, and therefore, it must be imported from the circulation across the blood-brain barrier (BBB) [70]. The BBB comprises endothelial cells in the capillary connected with tight junctions, astrocytic end-foot processes, pericytes, and neurons [71]. The endothelial cells offer highly selective permeability in the BBB by their specialized tight junction function. Thus, the BBB is provided with a neuronal system immune-privileged environment permitting only small molecules into the brain.

Free fatty acids (FFAs) are transported into the cytosol via cell membrane- and cytoplasmic fatty acid-binding proteins (FABPs) [12]. There are four classes of membrane fatty acid transport proteins present in the brain, such as fatty acid translocase (FAT/CD36), plasma membrane fatty acid-binding proteins (FABPpm), fatty acid transport proteins (FATPs), and several cytosolic fatty acid-binding proteins (FABPs) $[41,72,73]$. Additionally, another transporter, Mfsd2a (major facilitator superfamily domain-containing protein 2A), is present in the BBB [12]. Mfsd2a transports lysophosphatidylcholine (LPC)-DHA, but not unesterified DHA [12,74-76]. The DHA-LPC produced from DHA-containing phosphatidylcholine when acted upon by PLA1. A sterol regulatory element-binding protein regulates the activity of Mfsd2a to maintain a balance between de novo lipogenesis and exogenous uptake of LPC-DHA. The brain of the Mfsd2a-deficient mice had significantly reduced DHA levels and experienced loss of neurons in the hippocampus and cerebellum. The mice later developed microcephaly with severe cognitive deficits and anxiety. Altered plasma levels of Mfsd2a during pregnancy influence the placental transport of DHA and neurodevelopment in utero [77]. The maternal blood levels of Mfsd2a in the third trimester were inversely correlated to DHA-LPC in maternal plasma [77]. DHA or DHA-LPC is taken up by the endothelial cells via FAT/CD36, FATPs, or Mfsd2a. Plasma albumin binds both unesterified DHA and DHA-LPC.

Like LPC-DHA, the accretion of ARA to the brain from ARA-containing lysophospholipids is six-fold more efficient than for unesterified ARA [78]. The brain relies on different transport systems for shuttling the varied forms of the metabolized DHA across the BBB. Active pathways of DHA and ARA incorporation into the brain include members of the FABP family. In human brain microvessel endothelial cells, FAT/CD36 and FATP-1, FATP4 also transport fatty acids across the monolayer [73]. However, DHA incorporation into

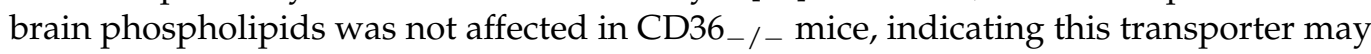
not be involved in the transport of DHA.

FABPs involve in the FFA uptake and transport to various intracellular compartments of a cell $[73,79]$. The expression of various FABP genes occurs at different developmental stages of the brain, as shown in animal studies. FABP3 is expressed in the brain after birth, and its expression levels increases until adulthood [80]. FABP4 is mainly expressed in grade IV astrocytomas and normal brain tissue [81], whereas FABP5 is expressed in the mid-term embryonic rat brain and reaches its peak at birth, then gradually decreases in postnatal life [80]. FABP7 is expressed mainly in radial glial cells at the early stages of brain development $[80,82]$. The level of FABP7 expression decreases starkly in the neonate and adult brain [80]. FABP7 plays a role in the establishment of the radial glial fiber system [82]. Moreover, FABP7 has been suggested to be associated with the decreased survival of glioblastoma patients [83-85].

FABPs have broad binding specificity, including the binding affinity for long-chain fatty acids ( $\geq$ c16), eicosanoids, bile salts, and PPARs $[41,86]$. Both FABP3 and FABP4 bind ARA with high affinity $[87,88]$, while FABP5 preferentially binds long-chain saturated fatty acids ( $c \geq 16$ ) [89]. FABP7 binds both DHA and ARA but with four-fold more affinity for DHA [90], indicating that DHA may be a preferred ligand for FABP7. Although FABP7, FABP5, and FABP3 can also bind different types of fatty acids [89,91].

FABP3, FABP5, and FABP7 are involved in both developing and mature adult brains [86,92]. Functional studies have demonstrated a variety of roles for FABPs in brain development, including the generation of neuronal and/or glial cells, differentiation, neuronal cell 
migration, and axis patterning. Like DHA, FABP7 increases the proliferation of neural stem cells and neural progenitor cells and differentiates into mature neurons both in vitro and in vivo $[93,94]$.

FABPs are multi-functional proteins, and complex signaling networks and transcription factors regulate their expression. FABPs are major downstream effectors of the ReelinDab1/Notch pathway that involves neuron-glia crosstalk during brain development. Since LCPUFAs and several FABPs are involved in brain development and function, it is important to further elucidate their roles in brain disorders' pathogenesis.

As FABPs are involved in developing, establishing, and maintaining the central nervous system, FABPs are implicated in the pathogenesis of Down syndrome. FABP7 is overexpressed in Down syndrome adult [95] and fetal brains [96], whereas FABP3 is significantly decreased in Down syndrome adult brains [95]. Furthermore, FABP7 upregulation correlates with PKNOX1 gene-dosage imbalance in the brains of Down syndrome patients. PKNOX1 is a POU domain protein that may directly control FABP7 expression by interacting with the Pbx/POU binding element of the FABP7 promoter [96]. Human FABP7 mRNA levels were significantly upregulated in the postmortem brains of schizophrenia patients. A correlation between an SNP variant within the second exon of human FABP7 and schizophrenia pathology was observed [97]. The impairment of prepulse inhibition (PPI) occurs in many brain disorders such as Alzheimer's disease, autism, bipolar disorders, Tourette syndrome, and schizophrenia [98]. The association between FABP7 and PPI status suggests roles of the FABP7 gene in the pathology of PPI-mediated neuropsychiatric and/or neurodegenerative diseases. The association of FABP3 and FABP5 with several neurodegenerative diseases is also reported $[99,100]$. DHA influences brain functions and protects from different brain tumors such as astrocytoma and glioma by binding to the FABP, resulting in the activation of transcription factor PPAR $\gamma$ to the nucleus-reduced cell migration, growth arrest, and apoptosis of tumor cells [101]. However, the roles of these proteins in human brain development are not well known.

\section{Structural and Functional Roles of DHA in the Human Brain}

The brain is known as the body's fattiest organ, containing phospholipids around $2 / 3$ of its weight. The brain harness $20 \%$ of its total energy from $\beta$-oxidation of fatty acids in the mitochondria of astrocytes. The presence of DHA on the membrane influences neuronal information transmission, signal transduction velocity, and interaction with ion channels or receptor proteins and their activity [102]. DHA is also predominantly present in cortical gray matter, representing approximately $15 \%$ of total fatty acids in the adult human prefrontal cortex. As a crucial structural ingredient of the brain, DHA comprises the regions of the cerebral cortex and synaptic membrane. Neuronal membranes have approximately $50 \%$ DHA [44]. DHA is also vital for hippocampal and cortical neurogenesis, neuronal migration, and outgrowth $[93,103,104]$.

The brain fatty acid levels, mostly LCPUFAs, are maintained via different mechanisms, as described above. The circulating plasma levels of DHA is positively related to cognitive abilities during aging and is inversely associated with decline in cognitive function. DHA, being a part of the cell membrane phospholipid, contributes to maintaining optimal fluidity and lipid raft assembly in the membranes, membrane electrical and antigenic signals of the cells. DHA also halts cell death by stimulating cell-cycle exit in neuro-progenitor cells $[93,105]$. DHA is involved in monoaminergic and cholinergic systems during brain development processes [52,106,107]. DHA has a long-term effect on serotonergic and dopaminergic systems during the fetal brain development in utero $[35,107,108]$. Data emphasized the importance of examining the long-term critical impact on brain development due to inadequate DHA supplies to the fetus during pregnancy. DHA stimulates neurite outgrowth in cell culture systems. Neurite outgrowth is an important process in the developing nervous system and also in the regeneration of nerves. The alpha linoleneic acid, 18:3n-3 (the precursor of DHA)-restricted diet decreased neurogenesis in rat dams' fetal brains, possibly due to the deficiency of DHA [103]. DHA 
influences gene expression, neurotransmission and protects the brain from oxidative stress during development [109]. DHA is an essential factor for neurogenesis, phospholipid synthesis, and turnover [93,110,111].

Again, DHA can act as a ligand for peroxisome proliferator-activated receptor-gamma $(\mathrm{PPAR} \gamma)$ and retinoid $X$ receptor (RXR). RXR plays a vital role in embryonic neurogenesis, neuronal plasticity, and catecholaminergic neuron differentiation along with retinoic acid receptors. RXR is highly expressed in the hippocampus [112,113]. The PPAR $\gamma-R X R$ heterodimer modulates early brain development by regulating transcription genes [112,114].

DHA also protects the developing brain from peroxidative damage of lipids and proteins [115-117]. DHA and eicosapentaenoic acid,20:5n-3 (EPA) were reported as suppressors of angiogenesis in cancer cells, but they stimulate angiogenesis in the placenta [45]. However, DHA and DHA-LPC may act as pro-angiogenic and anti-angiogenic depending on the concentration and microenvironments [118].

Several epidemiological data show an inverse association of low habitual dietary intake of DHA and a higher risk of brain diseases [2,119,120]. A diet containing high amounts of n-3 fats and/or a lower amount of n-6 fats was strongly associated with the lower incidence of Alzheimer's disease and other brain diseases [121-124]. Intake of DHA improves attention deficit hyperactivity disorder (ADHD), bipolar disorder, schizophrenia, impulsive behavior, and other brain disorders [20,123,125].

Nevertheless, the data of intervention studies with DHA supplements are conflicting, despite the fact that many such studies demonstrated an apparent benefit of DHA intake in brain function. Several studies failed to reproducibly show that the absence of DHA and its metabolites are involved in various adult brain diseases. More well-designed clinical trials considering background diets and genetic makeup are needed for definitive conclusions.

\section{Roles of DHA and Its Metabolites in the Brain}

DHA and its metabolites play vital roles in the functional brain development of the fetus in utero and infants and healthy brain function in adults. DHA and its metabolites play significant roles in cellular and biological functions. The oxidation of DHA by lipoxygenases produces several types of metabolites such as oxylipins that regulate various biochemical processes of the brain [126].

DHA stimulates membrane-associated G-protein-coupled receptor (GPR) 120 mediated gene activation to promote anti-inflammatory activities [127,128]. DHA also activates PPARs and upregulates the expression of genes responsible for increasing insulin sensitivity and reducing plasma triglyceride level and inflammation. [44]. DHA and its metabolites' signaling pathways are involved in neurogenesis, anti-nociceptive effects, anti-apoptotic effects, the plasticity of the synapse, $\mathrm{Ca}^{2+}$ homeostasis in the brain, and nigrostriatal activities [129]. DHA itself and its metabolites have a broad spectrum of actions at different levels and sites in the brain $[129,130]$. Figure 2 shows the DHA and EPA metabolites and their function in the brain.

DHA is converted to maresin 1(MaR1), neuroprotectin D1(NPD1), and resolvins by human 12-LOX, 15-LOX, and CYP or enzymatically by aspirin-treated COX-2. They play various functions in the brain. DHA is metabolized by the P450 system, cyclooxygenase, and lipoxygenase enzymes under different metabolic conditions. 14-HDHA: 14-hydroxydocosahexaenoic acid; 17-HDHA: 17-hydroxy-docosahexaenoic acid; 18-HEPE: 18-hydroxyeicosapentaenoic acid; LG R6: G protein-coupled receptor 6; ALX/Fpr2: N-formyl peptide receptor 2; BLT1: leukotriene B4 receptor; COX-2: cyclooxygenases; DHA: docosahexaenoic acid; EPA: eicosapentaenoic acid; GPR32/37: G protein-coupled receptor 32/37; LC-PUFAs: long-chain polyunsaturated fatty acids; LOX: lipoxygenases. 


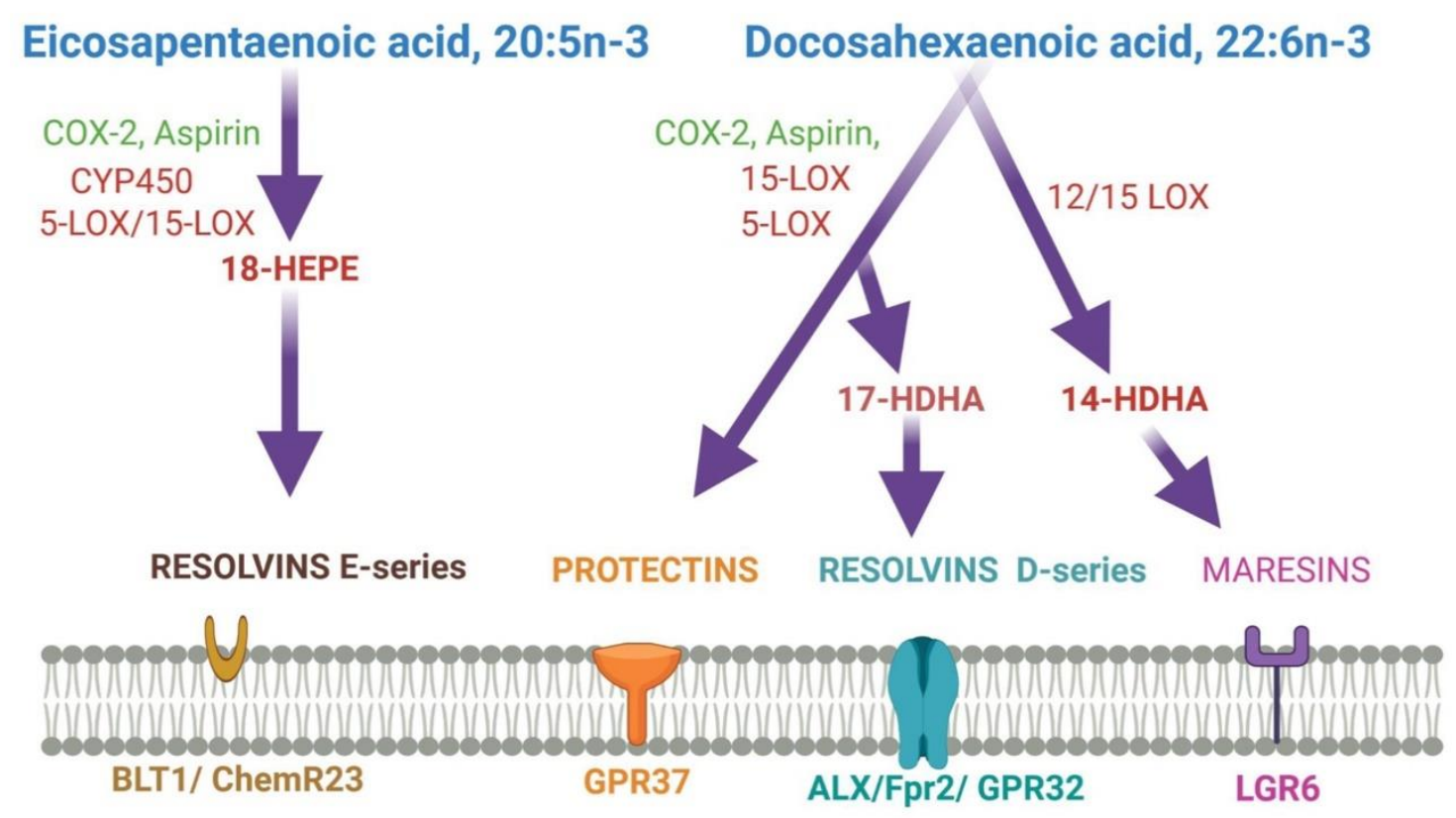

Figure 2. Metabolites of EPA and DHA, and their membrane receptors.

DHA-derived specialized pro-resolving mediators (SPMs) such as DHA epoxides, oxo-derivatives (EFOX) of DHA, neuroprostanes, ethanolamines, acylglycerols, docosahexaenoyl amides of amino acids, and branched DHA esters of hydroxy fatty acids play important roles in brain functions [131,132]. Additionally, epoxydocosapentaenoic acids (EDPs) and 22-hydroxydocosahexaenoic acids (22-HDoHEs) are produced from DHA [133,134]. DHA is mainly metabolized by enzymes such as 5-, 12- and 15-lipoxygenases (LOX), COX2 , and cytochrome P450 (CYP). As the most demanding by-products of DHA, resolvins are formed by either LOX15 or CYP or aspirin-treated COX-2 activity [28]. The LOX15-derived resolvins are homologous to CYP-, or aspirin-treated COX-2-derived resolvins [28]. As the inflammation resolution mediators, resolvins act via different G-protein coupled receptors (GPRs) [28,135]. Both resolvin D1 and aspirin-triggered resolvin D1 improve brain functions and impede neuronal death by down-regulating several factors such as NFkB, TLR4, CD200, and IL6R [136,137]. They even induce remote functional recovery after brain damage [136]. Both resolvin D2 and aspirin-triggered resolvin D2 protect from cerebral ischemic injury via phosphorylation ERK1/2. Subsequently, this pathway stimulates nNOS or eNOS to inhibit neuronal cell death and maintain BBB integrity by increasing zonula occludens1 [138]. Resolvin D3, resolvin D5, aspirin-triggered COX-2 -derived resolvin D3, and aspirin-triggered resolvin D5 halt the neuroinflammation [139,140]. However, the functions of other resolvins are still a mystery. Maresin (MaR), the anti-inflammatory pro-resolving mediator, is produced from DHA in macrophages during the inflammation, healing, and regeneration process [141-143]. MaR1 is predominant among other maresins. MaR1 decreases $\mathrm{LTB}_{4}$ synthesis and stimulates phagocytosis at the site of inflammation [144-146]. MaR1 enhances tissue repair by stimulating stem cell differentiation and plays an analgesic role through TRPV1-mediated response blockage $[145,147]$. MaR1 involves neurocognitive functions by regulating the infiltration of macrophages, regulating NF- $\mathrm{kB}$ signaling, oxidative stress, and cytokine release. Maresin 1 reduces neuroinflammation perioperative neurodegenerative disorders in an animal model [148]. MaR1 significantly affects the post-spinal cord injury model $[149,150]$.

Another SPM, neuroprotectin D1(NPD1), derived from DHA, improves cell survival and cell repair in brain disorders [151]. Like MaR1, NPD1 also possesses anti-inflammatory and neuroprotective activities [152]. In response to neuroinflammation, NPD1 is produced from endogenous DHA in the retina and brain $[153,154]$. Besides antiviral protection, NPD1 helps in neurocognitive functions [155-157]. NDP1 blocks the progression of Alzheimer's 
disease by stimulating the expression of PPAR $\gamma$, amyloid precursor protein- $\alpha$, and reducing the $\beta$-amyloid precursor protein [156]. Figure 3 describes DHA metabolites and their global effects on gene expression and second messenger systems affecting multiple cellular functions in the brain.

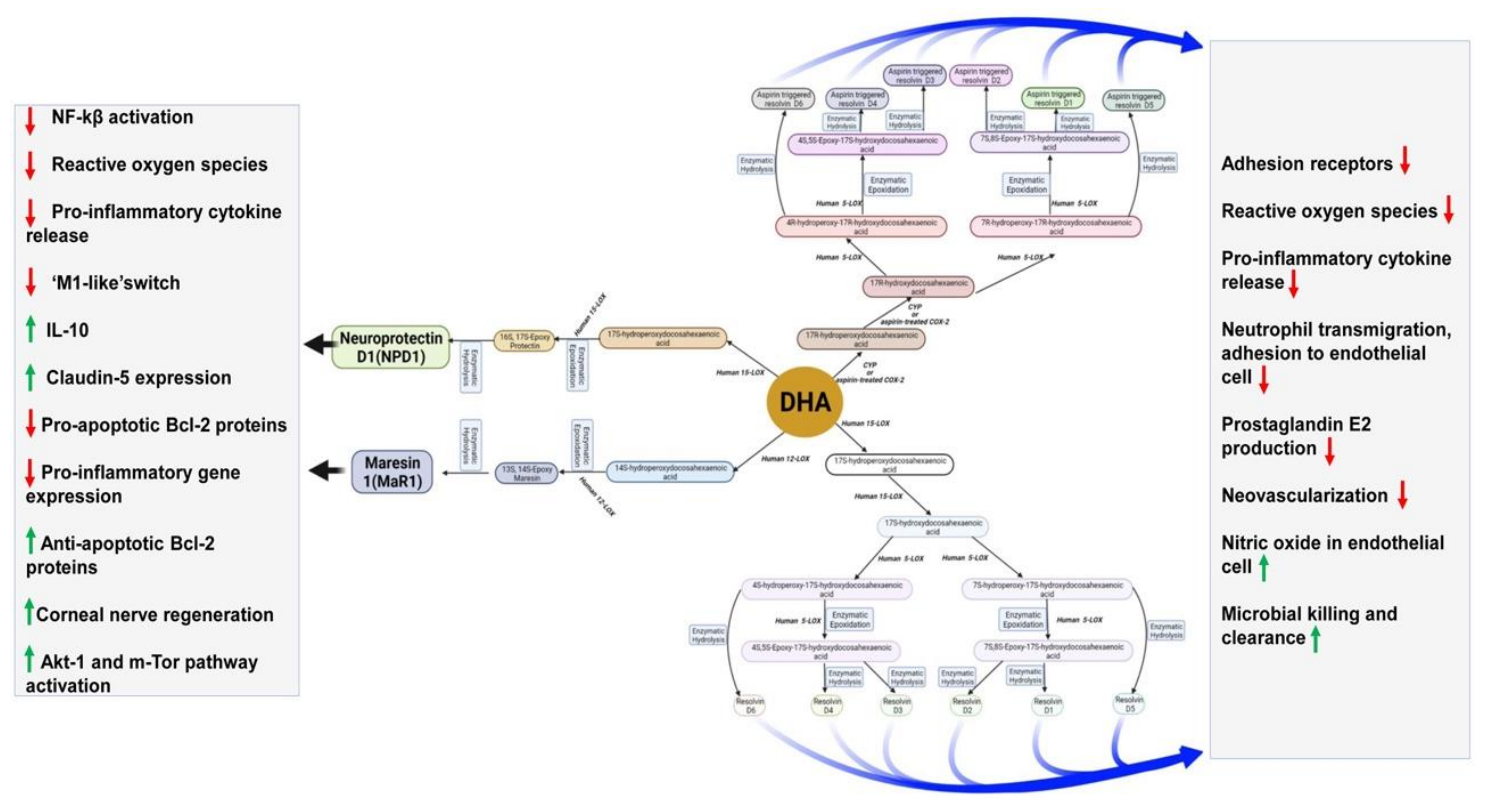

Figure 3. DHA metabolites formation and function in the brain.

Maresin 1(MaR1), neuroprotectin D1(NPD1), and resolvins are produced from DHA by human 12-LOX, 15-LOX, and CYP or aspirin-treated COX-2 enzymatically. These metabolites have multiple functions in the brain, which have been mentioned in the boxes. DHA is metabolized by the P450 system, cyclooxygenase, and lipoxygenase enzymes under different metabolic conditions.

Anti-inflammatory activities of EFOX and neuroprostanes protect neuroinflammation in various diseases, such as Parkinson's disease and Alzheimer's disease [158-160]. Another DHA derivative, docosahexaenoyl ethanolamide, improves mood, pain, inflammation status, hunger, and glucose uptake by the brain endocannabinoid system [161-166]. The function of DHA metabolites is summarized in Table 1.

DHA glyceryl ester regulates the intake of food and neuroinflammation, similarly to the way docosahexaenoyl ethanolamide uses the endocannabinoid system $[167,168]$. The endocannabinoid system plays an integral part in memory, cognition, and pain perception $[169,170]$. DHA conjugates via cannabinoid receptors reduce neuroinflammation and improve neurogenesis $[171,172]$.

DHA is involved in alleviating short-term stress, preventing anxiety and stress in later life $[132,173]$. DHA is reported to improve various psychiatric disorders such as schizophrenia, mood and anxiety disorders, obsessive-compulsive disorder, ADHD, autism, aggression, hostility and impulsivity, borderline personality disorder, substance abuse, and anorexia nervosa [174]. There is strong evidence that the consumption of marine fish reduces depression [175].

The mild symptoms of ADHD are corrected with DHA supplementation [176]. DHA was also shown to improve depressive symptoms of bipolar disorder by increasing $\mathrm{N}$ acetyl-aspartate brain levels without affecting mania [174]. Even IQ outcomes in children and cognitive function in the aging brain are improved by DHA supplementation [2,24]. DHA-derived anti-inflammatory eicosanoids' neuroprotection prevent Alzheimer's disease pathogenesis [177]. DHA may modulate the metabolism of cholesterol and apolipoprotein E, lipid raft assembly, and the cell signaling system in Alzheimer's disease [178,179]. DHA protects neuronal brain function by reducing NO production, calcium influx, and apoptosis 
while activating antioxidant enzymes such as glutathione peroxidase and glutathione reductase [180]. The second most prevalent neurodegenerative disease, Parkinson's disease, can be halted by DHA's neuroprotective role [180].

Table 1. Functions of DHA and ARA metabolites.

\begin{tabular}{|c|c|c|}
\hline Metabolites & Name & Biological Effects \\
\hline \multirow{6}{*}{ DHA Metabolites } & Maresins & $\begin{array}{l}\text { Resolution of inflammation, wound } \\
\text { healing, analgesic effects }\end{array}$ \\
\hline & Protectins & $\begin{array}{l}\text { Resolution of inflammation, } \\
\text { neuroprotection }\end{array}$ \\
\hline & Resolvins & $\begin{array}{l}\text { Resolution of inflammation and } \\
\text { wound healing }\end{array}$ \\
\hline & $\begin{array}{l}\text { Electrophilic oxo-derivatives } \\
\text { (EFOX) of DHA }\end{array}$ & $\begin{array}{l}\text { Anti-inflammatory, anti-proliferative } \\
\text { effects }\end{array}$ \\
\hline & Epoxides & Anti-hypertensive, analgesic actions \\
\hline & Neuroprostanes & Cardio-protection, wound healing \\
\hline \multirow{3}{*}{ DHA conjugates } & $\begin{array}{l}\text { Ethanolamines and glycerol } \\
\text { esters }\end{array}$ & $\begin{array}{l}\text { Neural development, } \\
\text { immunomodulation, metabolic } \\
\text { effects }\end{array}$ \\
\hline & $\begin{array}{l}\text { Branched fatty acid esters of } \\
\text { hydroxy fatty acids (FAHFA) }\end{array}$ & $\begin{array}{l}\text { Immuno-modulation, resolution of } \\
\text { inflammation }\end{array}$ \\
\hline & $\mathrm{N}$-acyl amides & $\begin{array}{l}\text { Metabolic regulation, } \\
\text { neuroprotection, neurotransmission }\end{array}$ \\
\hline \multirow[t]{2}{*}{ ARA metabolites } & Lipoxins A4 & $\begin{array}{l}\text { Lowers neuroinflammation by } \\
\text { inhibiting microglial activation }\end{array}$ \\
\hline & Lipoxins B4 & $\begin{array}{l}\text { Promotes neuroprotection from acute } \\
\text { and chronic injuries }\end{array}$ \\
\hline
\end{tabular}

\section{DHA Deficiency in Utero and Human Brain Function}

DHA deficiency is linked with different brain disorders such as major depressive and bipolar disorder [181,182]. DHA levels are positively correlated with improved learning and memory and reduced neuronal loss [24]. DHA deficiency affects epigenetic development in the feto-placental unit $[183,184]$. The improvement in attention scores, adaptability to new surroundings, mental development, memory performance, and hand-eye coordination are associated with higher maternal DHA delivery to the fetal brain $[7,185]$.

DHA deficiency during pregnancy suggests the lower development of language learning skills in children [186]. Even autistic spectrum disorder or ADHD among teenagers is associated with DHA deficiency $[187,188]$. Neurocognitive functional insufficiency in young adults or loneliness-related memory problems in middle age have been associated with DHA deficiency $[189,190]$. DHA deficiency in the third trimester significantly causes preterm brain development due to the insufficient maternal consumption of n-3 fatty acids. Even following delivery, infants are entirely dependent on breast milk or formula milk for DHA and ARA. Reduced DHA consumption during this critical brain development period may influence brain functionalities in adult life [191].

Dementia has shown an inverse relationship with regular marine fish consumption in different continents $[120,192]$ and higher blood DHA levels inversely related to dementia [193,194]. Various brain diseases/disorders, such as Alzheimer's disease, Parkinson's disease, Huntington's disease, schizophrenia, and mood disorders, are related to disturbed fatty acid signaling $[195,196]$. The most prevalent dementia is Alzheimer's disease, which is inversely related to brain DHA level. Serum DHA level reduces significantly, and its addition positively correlates with memory scores in elderly Alzheimer patients [119,197,198]. The plasma DHA level is significantly associated with the risk of Alzheimer's disease [199]. 
Intake of $200 \mathrm{mg}$ of DHA-containing fish per week reduces the risk of AD by 60\% [200]. However, different randomized controlled trials (RCTs) found mixed results with DHA supplementation. DHA alone or combined with ARA or the EPA found no significant neuropsychiatric status changes in Alzheimer's disease patients [123,124,201]. The neurodegenerative disorder, Parkinson's disease's etiology is unknown. However, its primary palliative treatment is dopamine-based therapy. Various animal studies found the neuroprotective effect of DHA in the Parkinson's disease model. DHA has been shown to improve L-DOPA-induced dyskinesia [202] and reduce dopaminergic neuron apoptosis in mouse models [121]. DHA supplements offer a beneficial neuroprotective effect for Parkinson's disease management [203].

Multiple factors influence serotonin biosynthesis and function. The brain's serotonin level correlates with various behavioral consequences, e.g., control of executive function, sensory gating, social behavior, and impulsivity [204]. Serotonin-related gene polymorphism is associated with mental illnesses, e.g., autism spectrum disorders, ADHD, bipolar disorder, schizophrenia, etc. DHA modulates the activity of serotonin in the brain. DHA increases serotonin receptor accessibility by increasing membrane fluidity in postsynaptic neurons [204]. Concentric serotonin and a low DHA level in the orbitofrontal cortex are correlated with schizophrenia [205].

Observational studies showed that ADHD also has a relationship with DHA levels. RCTs of DHA with EPA supplementation and the addition of medications have demonstrated significant improvement in ADHD symptoms [122,187,206-216]. However, DHA supplementation with methylphenidate did not improve ADHD symptoms [217].

There are mixed results in RCTs that have been observed in early psychosis symptoms improvement with DHA supplementation. When DHA is supplemented with EPA for at least 12 weeks, the functional improvement and reduction in psychiatric symptoms are visible in different studies [218-220]. DHA deficiency elicits the chances of schizophrenia by promoter hypermethylation of nuclear receptor genes RxR and PPAR, which results in the downregulation of the gamma-aminobutyric acid-ergic system and the prefrontal cortex involved in oligodendrocyte integrity [221]. Lower erythrocyte DHA status is associated with the development of bipolar disorder [222]. However, combined DHA and EPA supplementation for 6 weeks improved mania and depression among juvenile patients [223-225]. However, recent RCTs found DHA has no role in improving the symptoms of bipolar disorder [20].

\section{Can DHA Supplementation Improve Brain Function of Infants: Results of Clinical Trials}

Various RCTs proved significant effects of DHA supplementation on infant brain development in pregnancy. The meta-analytic study in 2007 found a static co-relation between visual growth and DHA supplementation in first year of life [125]. An RCT in 2011 showed DHA-supplemented 18-month-old children had higher index scores in mental development [8]. Other RCTs showed DHA-enriched fish oil supplemented children had significantly higher percentile ranks of the total number of gestures at 1 to 1.5 years of age [226]. DHA-formula-fed infants scored equal visual equity scores with breast-fed infants at the age of four [227]. The recent meta-analytic review also found the positive effects of seafood consumption in pregnancies in developing childhood neurocognitive function [53]. The supplementation of DHA to pregnant and nursing mothers and the first year of infant life have developed better cognitive ability. During the last trimester of pregnancy, fetal brain development demands a higher amount of DHA, which can be interrupted in the case of a preterm born baby and can result in mental growth retardation. Different RCTs showed that higher DHA-enriched formula (around 1\% of total fatty acids) is essential for the preterm baby for mental growth and development [24].

DHA supplemented along with EPA enhance the outcome for cognitive and mood disorders. However, conflicting data exist about the effect of DHA supplementation on cognition during childhood. The earlier RCT conducted in Australia and Indonesia did not show any improvement in general intelligence or attention among 6-10-year-old chil- 
dren following $88 \mathrm{mg} / \mathrm{d}$ DHA supplementation [228]. The DHA Oxford Learning and Behavior (DOLAB) study showed a significant improvement in brain function among aged 7-9-year-olds [229]. Another RCT showed improved memory and learning ability among 7-9-year-old children [230]. A few years ago, another RCT from Australia found no significant difference in academic performance between the DHA-supplemented and control groups [231]. Although the authors have mentioned their study's limitation that the final assessment was finished by less than half of the study population, DHA supplementation was low. The study was conducted with slightly older children, and in some cases, mothers did not give consent or provide data. The Third National Health and Nutrition Examination Survey (NHANES III) found a higher DHA supplementation effect in girls than boys, despite both sexes' receiving cognitive benefit [232]. The pregnant women need higher DHA supplementation for their own growth and for the growth and development of the newborn. Even the source of DHA and the ratio of EPA and DHA may influence the bioavailability of DHA.

A summary of a few recent clinical trials has been shown in the following Table 2. Although a slight improvement, these studies did not show any significant positive outcome from DHA supplementation effects on young children. However, a meta-analysis of DHA supplementation with the EPA improved childhood visual and psychomotor development without significant global IQ effects later in childhood [233]. However, there are no clinical data available where DHA supplementation was conducted before 14.5 weeks of the gestational period.

Table 2. Various clinical studies of DHA supplementation in mothers and infants about brain function.

\begin{tabular}{|c|c|c|}
\hline Study Name & Experimental Setting & Observed Outcome \\
\hline $\begin{array}{l}\text { The Kansas University DHA outcome study } \\
\text { (KUDOS) clinical trial }\end{array}$ & Cognitive and behavioral development & $\begin{array}{l}\text { Improvement of visual attention among } \\
\text { infants has been observed to reduce the } \\
\text { preterm birth risk [234]. }\end{array}$ \\
\hline $\begin{array}{l}\text { Effect of DHA supplementation vs. placebo on } \\
\text { developmental outcomes of toddlers born } \\
\text { preterm }\end{array}$ & Developmental outcomes of toddlers & $\begin{array}{l}\text { Daily supplementation of DHA did not } \\
\text { improve cognitive function and may adversely } \\
\text { affect language development and effortful } \\
\text { control in specific subgroups of children [235]. }\end{array}$ \\
\hline $\begin{array}{l}\text { Effect of DHA supplementation during } \\
\text { pregnancy on maternal depression and } \\
\text { neurodevelopment of young children }\end{array}$ & Neurodevelopmental outcome of children & $\begin{array}{c}\text { DHA supplementation during pregnancy did } \\
\text { not reduce postpartum depression in mothers, } \\
\text { neither did it improve cognitive and language } \\
\text { development in their offspring during early } \\
\text { childhood [236]. }\end{array}$ \\
\hline $\begin{array}{l}\text { Neurodevelopmental outcomes of preterm } \\
\text { infants fed high-amount DHA }\end{array}$ & Neurodevelopment at 18 months of age & $\begin{array}{l}\text { Bayley mental development index scores of } \\
\text { preterm infants overall born earlier than } 33 \\
\text { weeks were not affected but improved the } \\
\text { girls' Bayley mental development index scores. }\end{array}$ \\
\hline $\begin{array}{l}\text { Neurodevelopmental outcomes at } 7 \text { years } \\
\text { corrected age in preterm infants who were fed } \\
\text { high-dose DHA to term equivalent }\end{array}$ & Cognitive outcome detected at 18 months age & No evidence of benefit [237]. \\
\hline $\begin{array}{l}\text { Feeding preterm infant milk with a higher } \\
\text { dose of DHA than that used in current practice }\end{array}$ & Language or behavior in early childhood & $\begin{array}{l}\text { No clinically meaningful change to language } \\
\text { development or behavior were observed when } \\
\text { assessed in early childhood [238]. }\end{array}$ \\
\hline
\end{tabular}

\section{Roles of Arachidonic acid20:4n-6 (ARA) in Brain Development and Function}

In addition to DHA, the mother preferentially supplies ARA to the growing and developing brain via the placenta and breastfeeding. ARA uptake was found to be higher in early trimester trophoblast cells than EPA and DHA [239]. The ARA metabolism in the brain is suspected of having an altered profile in neurological, neurodegenerative, and psychiatric disorders. Using various knock-out models for enzymes involved in brain ARA metabolism, Bosetti showed that the ARA and its metabolites play a significant role in brain physiology via the PLA2/COX pathway [240]. The effects of DHA and ARA on body growth and brain functions were studied using delta-6-desaturase knock-out 
(D6D-KO) mice by feeding different combinations of PUFAs in milk formulations. The in vivo findings confirmed the complementary roles of ARA and DHA in body and brain development, respectively [241]. ARA may be required in a higher amount to support growth-promoting placental activities and the production of eicosanoids. In human milk, the amount of ARA typically exceeds the levels of DHA. Milk ARA content is also less varied than DHA, and, unlike DHA, ARA does not seem to be linked to maternal intake. There has been much discussion in recent years about the need for ARA and DHA in infant formula. Studies clearly show the requirement for both ARA and DHA in addition to the essential fatty acids (linoleic acid,18:2n-6 (LA), and ALA to support the optimal body, brain growth, and brain function. ARA is quantitatively the most common LCPUFA in the brain after DHA [242]. Although diverse roles of DHA are investigated, the roles of ARA in brain development and functions have not been investigated to a greater extent. Given that ARA and its precursor, LA, contribute significantly to the Western diet and its pleiotropic biological effects and its interactions with DHA, this n-6 LCPUFA is a crucial modifiable factor in brain development and preventive strategies of brain diseases. ARA corresponds to around $20 \%$ of the total amount of neuronal fatty acids and is mainly esterified in membrane phospholipids.

Several studies have suggested that the structure-function and metabolism of the brain depend on levels of ARA and DHA and interactions of their metabolites [29]. The recycling (de-esterification-re-esterification) of these two fatty acids in the brain are independently carried out by ARA- and DHA-selective enzymes. The ARA-mediated processes can be targeted or altered separately from the DHA-mediated processes by a dietary deficiency of n-3 PUFA or genetic manipulation. Therefore, in studies using n-3 PUFA deficiency models, the homeostatic mechanisms show DHA loss in the brain while increasing ARA metabolism. Further studies are required to understand the impact of the $n-6 / n-3$ ratio on the regulation of DHA-selective iPLA2 and COX-1 or ARA-selective CPLA2, sPLA2, and COX-2 and their effects on brain function and neuroinflammation.

ARA must either be consumed in the diet or synthesized from its precursor LA in the liver. The brain contains relatively low LA levels, and its conversion into ARA is minimum in the brain. Thus, the growing brain depends on a steady supply of ARA [243] from the maternal circulation or via breast milk. Although lipoproteins and lysophospholipids of plasma may contribute to brain ARA levels, their quantitative contribution is unknown. Upon its entry into the brain, ARA is activated by a long-chain acyl-CoA synthetase and can be esterified into the sn-2 position of phospholipids. During neurotransmission, the brain ARA cascade is initiated when ARA is released from synaptic membrane phospholipid by the neuroreceptor-initiated activation of cPLA $2 . \mathrm{PLA}_{2}$ is activated by dopaminergic, cholinergic, glutamatergic, and serotonergic stimulation via G-proteins or calcium [244]. Several PLA 2 are activated via serotonergic (5-hydroxytryptaminergic), glutamatergic, dopaminergic, and cholinergic receptors [244,245]. Usually, calcium-dependent cytosolic $\mathrm{PLA}_{2}\left(\mathrm{cPLA}_{2}\right)$ resides at the postsynaptic terminals, selective for releasing ARA, whereas calcium-independent PLA $_{2}$ is believed to release the DHA sn-2 position of phospholipids $[13,14]$. Upon its release, a portion of the unesterified ARA is converted to prostaglandins, leukotrienes, and lipoxins, a portion oxidized via $\beta$-oxidation, and the remainder (approximately $97 \%$ under basal conditions) is activated by ACSL and ultimately recycled and re-esterified into the sn-2 position of phospholipids [246]. An additional ARA is released by activated cytokine and glutamatergic N-methyl-d-aspartate receptors in conditions such as neuroinflammation and excitotoxicity. Although the signals that ARA and its derivatives relay are not entirely understood, they regulate blood flow, neuroinflammation, excitotoxicity, the sleep/wake cycle, and neurogenesis [247].

Like DHA, ARA is also directly involved in synaptic functions. The level of intracellular free ARA and the balance between the releasing and incorporating enzymes in membrane phospholipids may play critical roles in neuroinflammation and synaptic dysfunction. Both these events are observed in the murine model of Alzheimer's disease before the amyloid plaques and the neurofibrillary tangles, respectively formed by the two agents 
known for Alzheimer's disease agents, A $\beta$ peptide and hyperphosphorylated tau. Finally, western food, which contains excessive $n-6 / n-3$ ratios, might favor more ARA levels and influence Alzheimer's disease mechanisms.

A better understanding of the complex relationships between ARA and DHA and their brain mechanisms is required. Free ARA contributes to Alzheimer's disease progression via different pathways. ARA and derivatives are pro-inflammatory and participate in neuroinflammation. ARA is directly involved in synaptic functions as a retrograde messenger and a regulator of neuro mediator exocytosis. ARA also influences tau phosphorylation, and polymerization can compete with DHA. Moreover, ARA has pleiotropic effects on brain disease, and it may be used in the fight against brain diseases. The dietary ARA and brain diseases about DHA should be investigated further to prevent the disease.

The transgenic Alzheimer's disease murine model showed that dietary ARA produced opposite A $\beta$ production in Alzheimer's disease. Studies on the impact of dietary ARA on Alzheimer's disease are required to identify the underlying mechanisms of action. A reduced level of ARA in the temporal cortex of Alzheimer's patients was observed [248]; however, its relation with DHA and its metabolites is unknown. ARA involvement in Alzheimer's disease was mediated via $\mathrm{cPLA}_{2} \alpha$. However, a DHA-rich diet did not show such effects [249]. A diet containing 2\% ARA for 21 weeks increased $A \beta_{1-42}$ production and deposition in 24-week-old CRND8 mice [250].

ARA is involved in cell division and signaling during brain growth and development [251]. In addition, ARA mediates neuronal firing [252], signaling [253] and long-term potentiation [254]. The absolute levels of n-3 PUFAs and the ratio of n-6 and n-3 PUFA affect gene expression of controlling neurogenesis and neural function.

ARA maintains structural order of the membrane and hippocampal plasticity [255]. ARA also protects the brain against oxidative stress in the hippocampus region via PPAR $\gamma$ and synthesizes new proteins [256]. Released intracellular ARA activates protein kinases and ion channels, inhibits the uptake of neurotransmitters, and enhances synaptic transmission, and modulates neuronal excitability [251]. As ARA is involved in intracellular signaling, the optimum levels of intracellular free ARA must be steadily maintained. ARA also activates syntaxin-3 (STX-3), a plasma membrane protein involved in the growth and repair of neurites [257]. Neurite growth closely correlates with the ARA-mediated activation of STX-3 in membrane expansion at growth cones [257]. The neurite growth from the cell body is a critical step in neuronal development. ARA stimulates exocytosis by allowing the attachment of STX-3 with the fusogenic soluble N-ethylmaleimide-sensitive factor receptors (SNARE complex) [258]. The SNARE proteins are involved in producing a fusion of vesicular and plasma membranes in the brain. The formation of this SNARE complex mediated by ARA drives membrane fusion, leading to the release of vesicular cargo into the extracellular spaces [258]. $\alpha$-Synuclein plays a role in the development of Parkinson's disease, can sequester ARA and thus blocks the activation of the SNARE complex [258], suggesting the importance of ARA in synaptic transmission. All these data show the importance of ARA in cell signaling, trafficking, and the regulation of spatial-temporal interactions between cellular structures.

The most abundant prostaglandins in the brain are $\mathrm{PGD}_{2}$ and $\mathrm{PGE}_{2}$. They are synthesized from ARA by $\mathrm{PGD}_{2}$ and $\mathrm{PGE}_{2}$ synthases. COX-2 is overexpressed in the cortex and hippocampus of Alzheimer's disease patients [259]. $\mathrm{PGE}_{2}$ increases neuroinflammation and amplifies Alzheimer's disease pathology through various mechanisms.

Figure 4 describes different metabolites of ARA involved in brain function. ARAderived lipoxins are anti-inflammatory eicosanoids distinct from pro-inflammatory leukotriene and prostaglandin. Lipoxin biosynthesis occurs via two different pathways. Lipoxins mediate their action on endothelial cells to offer an inflammation resolution process. LipoxinA4 lowers neuroinflammation by reducing microglial activation. 5- Lipoxygenase (5-LOX) converts ARA into 5-HPETE and then 5-HETE or leukotriene A4 (LTA4). There is the increased expression of the dual enzyme 12/15-LOX and its products. 


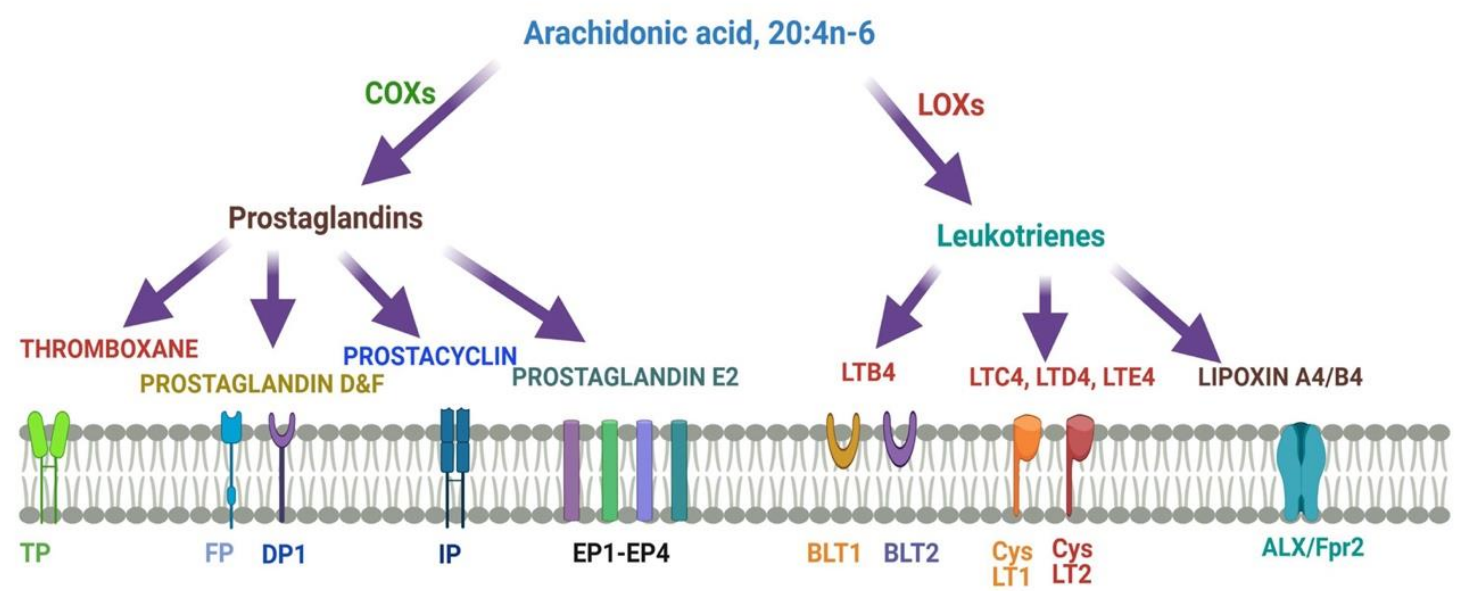

Figure 4. Metabolites of ARA and their receptors.

ARA is converted to lipoxinA4 or lipoxinB4 via two different pathways. Lipoxins mediate their action on endothelial cells to offer an inflammation resolution process. LipoxinA4 lowers neuroinflammation by reducing microglial activation. LTA4, LTB4, LTC4, LTD4, and LTE4 are leukotrienes A4, B4, C4, D4, and E4, respectively; DP1, EP1-EP4, FP, and IP, prostaglandin receptors; TP, thromboxane A2 receptor; BLT1 and BLT2, leukotriene B4 receptor; CysLT1 and CysLT2: cysteinyl leukotriene receptors; ALXR: lipoxins receptor.

12(S)-HETE and 15(S)-HETE were reported in frontal and temporal brain regions' cerebrospinal fluid, respectively, in Alzheimer's disease patients.

The endocannabinoids containing ARA are involved in Alzheimer's disease via the CB2 receptor. Although neuroinflammation is related to Alzheimer's disease, there is no evidence that higher brain contents of ARA would produce inflammation.

Several animal studies indicate that ARA has beneficial effects on cognition and synaptic plasticity [260]. An association between abilities of spatial memory and ARA content of the hippocampus was reported. ARA modulates $\mathrm{Kv}$ channels at the postsynaptic membrane, and influences long-term potentiation [261]. ARA induces presynaptic longterm depression associated with a $\mathrm{Ca}^{2+}$ influx and the activation of metabotropic glutamate receptors [261]. In addition, ARA can induce neurotransmitter exocytosis in the presynaptic neuron via activation of the soluble $\mathrm{N}$-ethylmaleimide-attachment receptors (SNARE). ARA induces the binding of syntaxin-1 to the SNARE complex in the presence of Munc18-1, which is a critical regulator of the process [262]. Although ARA's role in synaptic function is well documented, the benefit or drawback may depend on the delicate balance of ARA levels. Age and A $\beta$ concentration or other physiological factors could modify ARA's effects on synapse and neuronal cells. Additional work is now required to characterize dietary ARA's influence on associated brain diseases.

\section{Transport of ARA to the Developing Brain}

The transport of ARA to the brain tissue and inside the brain are not well understood, and more investigations are required for their nuanced characterization. The biological roles of several ACSLs and LPATs for incorporating ARA in the membrane phospholipids have been studied [246]. Some of them are relatively specific for ARA, such as ACLS4, LPIAT1, and LPCAT3. The polymorphisms and variations in their expression levels can affect ARA deposition in the different tissues, including the brain, despite identical ARA content in the food. Nutritional recommendations regarding the ARA intake must be based on the knowledge of such variations.

ARA's effects on brain signaling functions depend on the fact that free ARA is released from membrane phospholipid by $\mathrm{CPLA}_{2} \alpha$ or secretory PLA $\mathrm{P}_{2}$. The turnover of ARA in brain membrane phospholipids is involved bipolar disorder. The downregulation of the turnover 
correlates with the reduced expression of ARA-selective cPLA2 or acyl-CoA synthetase and COX-2 [244].

It is not known whether higher ARA amounts in specific phospholipid classes in the brain favor ARA released by these PLA 2 and lead to higher free ARA levels in neuronal or glial cells. Further studies are required to determine the effect of ARA brain uptake on its release and conversion into pro- or anti-inflammatory derivatives.

While the competition between $n-6$ and n- 3 fatty acids and their precursors for the desaturases, COXs, and LOXs are known, little is known on the competition between ARA and DHA in incorporation in the brain. Mfsd2A transports DHA to the brain in the form of DHA-LPC [74], but brain ARA content was increased by 30\% in Mfsd2A knockout mice, whereas that of DHA was reduced by $58 \%$. These fatty acid changes were accompanied by neuronal loss in the hippocampus and cerebellum with severe cognitive deficits and anxiety. Therefore, the deposition of ARA to the brain is not altered by the reduced expression of Mfsd2A. However, under this circumstance, ARA replaced DHA in phospholipids but could not play the roles of DHA in neuronal functions [74].

FABPs also have different affinities for ARA and DHA. FABP5 and FABP7 are more selective for DHA, whereas FABP3 binds ARA with much higher affinity [263,264]. Regarding fatty acid metabolizing enzymes, DHA is preferentially used as a substrate by ACSL6 [265] and calcium-independent group VI PLA 2 [266], whereas ACSL4 and group IV cPLA $_{2}$ used ARA as the preferred substrate.

ARA and DHA are preferentially incorporated in different lipid fractions of the brain regions, suggesting a differential role of these lipid biomolecules. ARA is concentrated into brain inositol phospholipid (PL), ethanolamine plasmalogens lipid fractions, while DHA is accumulated in serine and ethanolamine PL fractions of the synaptic membranes. ARA-rich PL is more enriched in white matter (myelinated regions) than grey matter, and there are regional differences in ARA and DHA in the brain. The DHA, ARA, and adrenic acid (22:4n-6) are the most abundant PUFAs in the brain. The preterm infants had less DHA and a lower DHA/ARA ratio in both the brain and the retina than term infants. [267] The mean proportions of ARA were higher in the early placenta than term, while its immediate precursor dihomo-gamma-linolenic acid,20:3n-6 (DGLA) was higher in term than the early placenta. The increased presence of ARA during early placentation supports its organogenesis and vascularization activities. In contrast, the enhanced proportions of DGLA favors the optimal blood flow to sustain fetal growth by their vasorelaxant and anti-platelet effects of $\mathrm{PGE}_{1}$-like activities $[268,269]$. ARA and DHA are required to replenish brain injury, vascular regulation, and brain development in preterm babies. ARA is needed to support endothelial cells during brain injury, while DHA is required to support membrane fluidity for the receptors and the linear growth and network of neuronal cells. The neuroprotective actions of DHA in preterm are manifested with anti-inflammatory initiation and resolutions by its own and its signaling lipid mediators in particular. ARA and DHA produced different sets of pro-resolving lipid bioactive. Lipoxins are derived from ARA, while resolvin (neuro) protectin and maresins are derived from EPA and DHA. LXA4 receptor staining in the brain indicates that lipoxinA4 lowers neuroinflammation and brain edema during brain injury [270]. The anti-inflammatory lipoxinA4 acts as an endogenous allosteric modulator of the cannabinoid receptor [271]. Thus, in contrast to PGE2, which shows pro-inflammatory actions, lipoxins offer an inflammation resolution process.

\section{Conclusions}

The essentiality of both DHA and ARA is known by the fact that these fatty acids make up $20 \%$ of the brain's fatty acids. The mother is required to supply these two fatty acids preferentially during the critical period of brain development via the placenta in utero and breastfeeding postnatally. However, the data on maternal and infant nutritional intakes are not yet consistent, despite the fact that DHA's impact on brain development and function has been investigated extensively for the last two decades. Due to some compounded variables and conflicting reports on the association with LCPUFA supplementation and 
cognitive development, it imperative to determine optimum DHA doses in the presence of ARA for optimum brain development in infants [272-274].

The mean concentrations of DHA and ARA in breast milk can vary based on the maternal diet [260]. The group with the highest levels of DHA showed decreased ARA levels in two brain areas, suggesting the competition of DHA with ARA. Still, the absolute levels of ARA and DHA could be more important than their ratio, in particular with the preterm infant. ARA supports the first year of developmental growth as the conditional deficiency of ARA is established in preterm infants [60].

The optimal balance of DHA and ARA intake during infancy is still unknown, but the current best practice advises that the amount of DHA in infant formula should not exceed the amount of ARA [275].

The high doses of DHA in formula may suppress the benefits of ARA. The preterm infant who received formula with the $n-6 / n-3$ ratio of 2:1 showed a higher level of LCPUFAs and improved psychomotor development than the $n-6 / n-3$ ratio of the $1: 1$ group, suggesting an ARA and DHA ratio of 2:1 in the formula for the very preterm infant [276]. Thus, the common requirement for nutritional supports needs both ARA and DHA for vascular and neuronal development, in particular with pregnancies where the supply of these nutrients halted prematurely [277]. The supplementation of DHA:ARA in infant formulas ranges from 1:1 to 1:2. The present recommendations with DHA and ARA levels are that $0.2 \%$ to $0.4 \%$ and $0.35 \%$ to $0.7 \%$ of total fatty acids are appropriate [278]. The formula should reflect human milk composition for optimal neurocognitive benefits. Both ARA and DHA are necessary for fetal neurodevelopment, and a deficiency in one may compromise growth. However, further works are required to understand the complementary roles of ARA and DHA in neurodevelopment.

Author Contributions: Conceptualization, A.K.D.; Methodology, A.K.D. and S.B.; Investigation, A.K.D. Original Draft Preparation A.K.D.; Writing-Review and Editing, A.K.D., S.B., R.M.; A.B., S.P.; Visualization, R.M., S.B. and A.K.D.; Supervision, A.K.D. All authors have read and agreed to the published version of the manuscript.

Funding: This work is supported in part by the grants from Throne Holst Foundation and the Faculty of Medicine, University Oslo, Norway.

Conflicts of Interest: The authors express no conflict of interest.

\begin{abstract}
Abbreviations
ARA: arachidonic acid; AD: Alzheimer's disease; ADHD: attention deficit hyperactivity disorder; ALA: $\alpha$-linolenic acid, 18:3n-3; COX: cyclooxygenase; DHA: docosahexaenoic acid,22:6n-3; EPA: eicosapentaenoic acid,20:5n-3; LCPUFAs: long-chain polyunsaturated fatty acids; LOX: lipoxygenases; NO: nitric oxide; PUFAs: polyunsaturated fatty acids; RCT: randomized controlled trial.
\end{abstract}

\title{
References
}

1. Nyaradi, A.; Li, J.; Hickling, S.; Foster, J.; Oddy, W.H. The role of nutrition in children's neurocognitive development, from pregnancy through childhood. Front. Hum. Neurosci. 2013, 7, 97. [CrossRef]

2. Lauritzen, L.; Brambilla, P.; Mazzocchi, A.; Harslof, L.B.; Ciappolino, V.; Agostoni, C. DHA Effects in brain development and function. Nutrients 2016, 8, 6. [CrossRef]

3. Martinez, M.; Conde, C.; Ballabriga, A. Some chemical aspects of human brain development. II. Phosphoglyceride fatty acids. Pediatr. Res. 1974, 8, 93-102. [CrossRef]

4. Clandinin, M.T.; Chappell, J.E.; Leong, S.; Heim, T.; Swyer, P.R.; Chance, G.W. Intrauterine fatty acid accretion rates in human brain: Implications for fatty acid requirements. Early Hum. Dev. 1980, 4, 121-129. [CrossRef]

5. Agostoni, C.; Trojan, S.; Bellu, R.; Riva, E.; Giovannini, M. Neurodevelopmental quotient of healthy term infants at 4 months and feeding practice: The role of long-chain polyunsaturated fatty acids. Pediatr. Res. 1995, 38, 262-266. [CrossRef] [PubMed]

6. Agostoni, C.; Trojan, S.; Bellu, R.; Riva, E.; Bruzzese, M.G.; Giovannini, M. Developmental quotient at 24 months and fatty acid composition of diet in early infancy: A follow up study. Arch. Dis. Child 1997, 76, 421-424. [CrossRef] [PubMed]

7. Helland, I.B.; Smith, L.; Saarem, K.; Saugstad, O.D.; Drevon, C.A. Maternal supplementation with very-long-chain n-3 fatty acids during pregnancy and lactation augments children's IQ at 4 years of age. Pediatrics 2003, 111, e39-e44. [CrossRef] [PubMed] 
8. Drover, J.R.; Hoffman, D.R.; Castañeda, Y.S.; Morale, S.E.; Garfield, S.; Wheaton, D.H.; Birch, E.E. Cognitive function in 18-monthold term infants of the DIAMOND study: A randomized, controlled clinical trial with multiple dietary levels of docosahexaenoic acid. Early Hum. Dev. 2011, 87, 223-230. [CrossRef]

9. Innis, S.M. Perinatal biochemistry and physiology of long-chain polyunsaturated fatty acids. J. Pediatr. 2003, 143, S1-S8. [CrossRef]

10. Jensen, C.L.; Voigt, R.G.; Prager, T.C.; Zou, Y.L.; Fraley, J.K.; Rozelle, J.C.; Turcich, M.R.; Llorente, A.M.; Anderson, R.E.; Heird, W.C. Effects of maternal docosahexaenoic acid intake on visual function and neurodevelopment in breastfed term infants. Am. J. Clin. Nutr. 2005, 82, 125-132. [CrossRef]

11. Dutta-Roy, A.K. Transport mechanisms for long-chain polyunsaturated fatty acids in the human placenta. Am. J. Clin. Nutr. 2000, 71, 315S-322S. [CrossRef]

12. Basak, S.; Mallick, R.; Duttaroy, A.K. Maternal docosahexaenoic acid status during pregnancy and its impact on infant neurodevelopment. Nutrients 2020, 12, 3615. [CrossRef]

13. Lauritzen, L.; Carlson, S.E. Maternal fatty acid status during pregnancy and lactation and relation to newborn and infant status. Matern. Child Nutr. 2011, 7, 41-58. [CrossRef] [PubMed]

14. Browning, L.M.; Walker, C.G.; Mander, A.P.; West, A.L.; Madden, J.; Gambell, J.M.; Young, S.; Wang, L.; Jebb, S.A.; Calder, P.C. Incorporation of eicosapentaenoic and docosahexaenoic acids into lipid pools when given as supplements providing doses equivalent to typical intakes of oily fish. Am. J. Clin. Nutr. 2012, 96, 748-758. [CrossRef]

15. Innis, S.M.; Friesen, R.W. Essential n-3 fatty acids in pregnant women and early visual acuity maturation in term infants. Am. J. Clin. Nutr. 2008, 87, 548-557. [CrossRef] [PubMed]

16. Yavin, E.; Himovichi, E.; Eilam, R. Delayed cell migration in the developing rat brain following maternal omega 3 alpha linolenic acid dietary deficiency. Neuroscience 2009, 162, 1011-1022. [CrossRef] [PubMed]

17. Su, K.P. Biological mechanism of antidepressant effect of omega-3 fatty acids: How does fish oil act as a 'mind-body interface'? Neurosignals 2009, 17, 144-152. [CrossRef] [PubMed]

18. Su, K.P.; Matsuoka, Y.; Pae, C.U. Omega-3 polyunsaturated fatty acids in prevention of mood and anxiety disorders. Clin. Psychopharmacol. Neurosci. 2015, 13, 129-137. [CrossRef] [PubMed]

19. Brunst, K.J.; Enlow, M.B.; Kannan, S.; Carroll, K.N.; Coull, B.A.; Wright, R.J. Effects of prenatal social stress and maternal dietary fatty acid ratio on infant temperament: Does race matter? Epidemiology 2014, 4. [CrossRef]

20. Ciappolino, V.; DelVecchio, G.; Prunas, C.; Andreella, A.; Finos, L.; Caletti, E.; Siri, F.; Mazzocchi, A.; Botturi, A.; Turolo, S.; et al. The Effect of DHA supplementation on cognition in patients with bipolar disorder: An exploratory randomized control trial. Nutrients 2020, 12, 708. [CrossRef]

21. Clayton, E.H.; Hanstock, T.L.; Hirneth, S.J.; Kable, C.J.; Garg, M.L.; Hazell, P.L. Long-chain omega-3 polyunsaturated fatty acids in the blood of children and adolescents with juvenile bipolar disorder. Lipids 2008, 43, 1031-1038. [CrossRef]

22. Hahn-Holbrook, J.; Fish, A.; Glynn, L.M. Human milk omega-3 fatty acid composition is associated with infant temperament. Nutrients 2019, 11, 2964. [CrossRef] [PubMed]

23. Grey, K.R.; Davis, E.P.; Sandman, C.A.; Glynn, L.M. Human milk cortisol is associated with infant temperament. Psychoneuroendocrinology 2013, 38, 1178-1185. [CrossRef]

24. Weiser, M.J.; Butt, C.M.; Mohajeri, M.H. Docosahexaenoic acid and cognition throughout the lifespan. Nutrients 2016, 8, 99. [CrossRef]

25. Lin, P.Y.; Su, K.P. A meta-analytic review of double-blind, placebo-controlled trials of antidepressant efficacy of omega-3 fatty acids. J. Clin. Psychiatry 2007, 68, 1056-1061. [CrossRef] [PubMed]

26. Bhatia, H.S.; Agrawal, R.; Sharma, S.; Huo, Y.X.; Ying, Z.; Gomez-Pinilla, F. Omega-3 fatty acid deficiency during brain maturation reduces neuronal and behavioral plasticity in adulthood. PLoS ONE 2011, 6, e28451. [CrossRef]

27. Mallick, R.; Basak, S.; Duttaroy, A.K. Docosahexaenoic acid,22:6n-3: Its roles in the structure and function of the brain. Int. J. Develop. Neurosci. Off. J. Int. Soc. Develop. Neurosci. 2019, 79, 21-31. [CrossRef] [PubMed]

28. Duvall, M.G.; Levy, B.D. DHA- and EPA-derived resolvins, protectins, and maresins in airway inflammation. Eur. J. Pharmacol. 2016, 785, 144-155. [CrossRef] [PubMed]

29. Contreras, M.A.; Rapoport, S.I. Recent studies on interactions between n-3 and n-6 polyunsaturated fatty acids in brain and other tissues. Curr. Opin. Lipidol. 2002, 13, 267-272. [CrossRef]

30. Colombo, J.; Carlson, S.E.; Cheatham, C.L.; Shaddy, D.J.; Kerling, E.H.; Thodosoff, J.M.; Gustafson, K.M.; Brez, C. Long-term effects of LCPUFA supplementation on childhood cognitive outcomes. Am. J. Clin. Nutr. 2013, 98, 403-412. [CrossRef]

31. Lepping, R.J.; Honea, R.A.; Martin, L.E.; Liao, K.; Choi, I.Y.; Lee, P.; Papa, V.B.; Brooks, W.M.; Shaddy, D.J.; Carlson, S.E.; et al. Long-chain polyunsaturated fatty acid supplementation in the first year of life affects brain function, structure, and metabolism at age nine years. Dev. Psychobiol. 2019, 61, 5-16. [CrossRef] [PubMed]

32. McNamara, R.K.; Carlson, S.E. Role of omega-3 fatty acids in brain development and function: Potential implications for the pathogenesis and prevention of psychopathology. Prostaglandins Leukot. Essent. Fatty Acids 2006, 75, 329-349. [CrossRef] [PubMed]

33. Montes, R.; Chisaguano, A.M.; Castellote, A.I.; Morales, E.; Sunyer, J.; Lopez-Sabater, M.C. Fatty-acid composition of maternal and umbilical cord plasma and early childhood atopic eczema in a Spanish cohort. Eur. J. Clin. Nutr. 2013, 67, 658-663. [CrossRef] [PubMed] 
34. Kuipers, R.S.; Luxwolda, M.F.; Offringa, P.J.; Boersma, E.R.; Dijck-Brouwer, D.A.; Muskiet, F.A. Fetal intrauterine whole body linoleic, arachidonic and docosahexaenoic acid contents and accretion rates. Prostaglandins Leukot. Essent. Fatty Acids 2012, 86, 13-20. [CrossRef]

35. Innis, S.M. Essential fatty acids in growth and development. Prog. Lipid Res. 1991, 30, 39-103. [CrossRef]

36. Martinez, M.; Mougan, I. Fatty acid composition of human brain phospholipids during normal development. J. Neurochem. 1998, 71, 2528-2533. [CrossRef] [PubMed]

37. Salem, N., Jr.; Wegher, B.; Mena, P.; Uauy, R. Arachidonic and docosahexaenoic acids are biosynthesized from their 18-carbon precursors in human infants. Proc. Natl. Acad. Sci. USA 1996, 93, 49-54. [CrossRef]

38. Dijck-Brouwer, D.A.; Hadders-Algra, M.; Bouwstra, H.; Decsi, T.; Boehm, G.; Martini, I.A.; Boersma, E.R.; Muskiet, F.A. Lower fetal status of docosahexaenoic acid, arachidonic acid and essential fatty acids is associated with less favorable neonatal neurological condition. Prostaglandins Leukot. Essent. Fatty Acids 2005, 72, 21-28. [CrossRef]

39. Sherry, C.L.; Oliver, J.S.; Marriage, B.J. Docosahexaenoic acid supplementation in lactating women increases breast milk and plasma docosahexaenoic acid concentrations and alters infant omega 6:3 fatty acid ratio. Prostaglandins Leukot. Essent. Fatty Acids 2015, 95, 63-69. [CrossRef]

40. Cetin, I.; Alvino, G.; Cardellicchio, M. Long chain fatty acids and dietary fats in fetal nutrition. J. Physiol. 2009. [CrossRef]

41. Duttaroy, A.K. Transport of fatty acids across the human placenta: A review. Prog. Lipid Res. 2009, 48, 52-61. [CrossRef]

42. Innis, S.M. Impact of maternal diet on human milk composition and neurological development of infants. Am. J. Clin. Nutr. 2014, 99, 734S-741S. [CrossRef] [PubMed]

43. Hsieh, A.T.; Brenna, J.T. Dietary docosahexaenoic acid but not arachidonic acid influences central nervous system fatty acid status in baboon neonates. Prostaglandins Leukot. Essent. Fatty Acids 2009, 81, 105-110. [CrossRef]

44. Calder, P.C. The DHA content of a cell membrane can have a significant influence on cellular behaviour and responsiveness to signals. Ann. Nutrit. Metab. 2016, 69, 8-21. [CrossRef]

45. Basak, S.; Das, M.K.; Duttaroy, A.K. Fatty acid-induced angiogenesis in first trimester placental trophoblast cells: Possible roles of cellular fatty acid-binding proteins. Life Sci. 2013, 93, 755-762. [CrossRef] [PubMed]

46. Johnsen, G.M.; Basak, S.; Weedon-Fekjaer, M.S.; Staff, A.C.; Duttaroy, A.K. Docosahexaenoic acid stimulates tube formation in first trimester trophoblast cells, HTR8/SVneo. Placenta 2011, 32, 626-632. [CrossRef]

47. Khong, Y.; Brosens, I. Defective deep placentation. Best Pract. Res. Clin. Obstet. Gynaecol. 2011, 25, 301-311. [CrossRef]

48. Campbell, F.M.; Dutta-Roy, A.K. Plasma membrane fatty acid-binding protein (FABPpm) is exclusively located in the maternal facing membranes of the human placenta. FEBS Lett. 1995, 375, 227-230. [CrossRef]

49. Bourre, J.M. Dietary omega-3 fatty acids for women. Biomed. Pharmacother. 2007, 61, 105-112. [CrossRef]

50. Jorgensen, M.H.; Nielsen, P.K.; Michaelsen, K.F.; Lund, P.; Lauritzen, L. The composition of polyunsaturated fatty acids in erythrocytes of lactating mothers and their infants. Matern. Child. Nutr. 2006, 2, 29-39. [CrossRef] [PubMed]

51. Koletzko, B.; Schmidt, E.; Bremer, H.J.; Haug, M.; Harzer, G. Effects of dietary long-chain polyunsaturated fatty acids on the essential fatty acid status of premature infants. Eur. J. Pediatr. 1989, 148, 669-675. [CrossRef]

52. Innis, S.M. Chapter 10 Essential fatty acid metabolism during early development. Biol. Grow. Anim. 2005. [CrossRef]

53. Hibbeln, J.R.; Spiller, P.; Brenna, J.T.; Golding, J.; Holub, B.J.; Harris, W.S.; Kris-Etherton, P.; Lands, B.; Connor, S.L.; Myers, G.; et al. Relationships between seafood consumption during pregnancy and childhood and neurocognitive development: Two systematic reviews. Prostaglandins Leukot. Essent. Fatty Acids 2019, 151, 14-36. [CrossRef]

54. Oddy, W.H.; Kendall, G.E.; Li, J.; Jacoby, P.; Robinson, M.; de Klerk, N.H.; Silburn, S.R.; Zubrick, S.R.; Landau, L.I.; Stanley, F.J. The long-term effects of breastfeeding on child and adolescent mental health: A pregnancy cohort study followed for 14 years. J. Pediatr. 2010, 156, 568-574. [CrossRef] [PubMed]

55. Marangoni, F.; Agostoni, C.; Lammardo, A.M.; Giovannini, M.; Galli, C.; Riva, E. Polyunsaturated fatty acid concentrations in human hindmilk are stable throughout 12-months of lactation and provide a sustained intake to the infant during exclusive breastfeeding: An Italian study. Br. J. Nutr. 2000, 84, 103-109. [CrossRef]

56. Brenna, J.T.; Varamini, B.; Jensen, R.G.; Diersen-Schade, D.A.; Boettcher, J.A.; Arterburn, L.M. Docosahexaenoic and arachidonic acid concentrations in human breast milk worldwide. Am. J. Clin. Nutr. 2007, 85, 1457-1464. [CrossRef]

57. Makrides, M.; Neumann, M.A.; Gibson, R.A. Effect of maternal docosahexaenoic acid (DHA) supplementation on breast milk composition. Eur. J. Clin. Nutr. 1996, 50, 352-357. [PubMed]

58. Lattka, E.; Rzehak, P.; Szabo, E.; Jakobik, V.; Weck, M.; Weyermann, M.; Grallert, H.; Rothenbacher, D.; Heinrich, J.; Brenner, H.; et al. Genetic variants in the FADS gene cluster are associated with arachidonic acid concentrations of human breast milk at 1.5 and 6 mo postpartum and influence the course of milk dodecanoic, tetracosenoic, and trans-9-octadecenoic acid concentrations over the duration of lactation. Am. J. Clin. Nutr. 2011, 93, 382-391. [CrossRef]

59. Van Goor, S.A.; Dijck-Brouwer, D.A.; Hadders-Algra, M.; Doornbos, B.; Erwich, J.J.; Schaafsma, A.; Muskiet, F.A. Human milk arachidonic acid and docosahexaenoic acid contents increase following supplementation during pregnancy and lactation. Prostaglandins Leukot. Essent. Fatty Acids 2009, 80, 65-69. [CrossRef] [PubMed]

60. Carlson, S.E.; Werkman, S.H.; Peeples, J.M.; Cooke, R.J.; Tolley, E.A. Arachidonic acid status correlates with first year growth in preterm infants. Proc. Natl. Acad. Sci. USA 1993, 90, 1073-1077. [CrossRef]

61. Uauy-Dagach, R.; Mena, P. Nutritional role of omega-3 fatty acids during the perinatal period. Clin. Perinatol. 1995, 22, 157-175. [CrossRef] 
62. Jimenez, M.J.; Bocos, C.; Panadero, M.; Herrera, E. Fish oil diet in pregnancy and lactation reduces pup weight and modifies newborn hepatic metabolic adaptations in rats. Eur. J. Nutr. 2017, 56, 409-420. [CrossRef]

63. Simopoulos, A.P. An increase in the omega-6/omega-3 fatty acid ratio increases the risk for obesity. Nutrients $2016,8,128$. [CrossRef] [PubMed]

64. Cohen, J.T.; Bellinger, D.C.; Connor, W.E.; Shaywitz, B.A. A quantitative analysis of prenatal intake of n-3 polyunsaturated fatty acids and cognitive development. Am. J. Prev. Med. 2005, 29, 366-374. [CrossRef] [PubMed]

65. Dunstan, J.A.; Simmer, K.; Dixon, G.; Prescott, S.L. Cognitive assessment of children at age 2(1/2) years after maternal fish oil supplementation in pregnancy: A randomised controlled trial. Arch. Dis. Child Fetal. Neonatal. Ed. 2008, 93, F45-F50. [CrossRef] [PubMed]

66. Oddy, W.H.; Li, J.; Whitehouse, A.J.; Zubrick, S.R.; Malacova, E. Breastfeeding duration and academic achievement at 10 years. Pediatrics 2011, 127, e137-e145. [CrossRef]

67. Kramer, M.S.; Aboud, F.; Mironova, E.; Vanilovich, I.; Platt, R.W.; Matush, L.; Igumnov, S.; Fombonne, E.; Bogdanovich, N.; Ducruet, T.; et al. Breastfeeding and child cognitive development: New evidence from a large randomized trial. Arch. Gen. Psychiatry 2008, 65, 578-584. [CrossRef]

68. Caspi, A.; Williams, B.; Kim-Cohen, J.; Craig, I.W.; Milne, B.J.; Poulton, R.; Schalkwyk, L.C.; Taylor, A.; Werts, H.; Moffitt, T.E. Moderation of breastfeeding effects on the IQ by genetic variation in fatty acid metabolism. Proc. Natl. Acad. Sci. USA 2007, 104, 18860-18865. [CrossRef] [PubMed]

69. Van Elswyk, M.E.; Kuratko, C. Achieving adequate DHA in maternal and infant diets. J. Am. Diet Assoc. 2009, 109, 403-404. [CrossRef] [PubMed]

70. Innis, S.M. Dietary omega 3 fatty acids and the developing brain. Brain Res. 2008, 1237, 35-43. [CrossRef] [PubMed]

71. Kadry, H.; Noorani, B.; Cucullo, L. A blood-brain barrier overview on structure, function, impairment, and biomarkers of integrity. Fluids Barriers CNS 2020, 17, 69. [CrossRef]

72. Dutta-Roy, A.K. Cellular uptake of long-chain fatty acids: Role of membrane-associated fatty-acid-binding/transport proteins. Cell. Mol. Life Sci. 2000, 57, 1360-1372. [CrossRef]

73. Mitchell, R.W.; On, N.H.; Del Bigio, M.R.; Miller, D.W.; Hatch, G.M. Fatty acid transport protein expression in human brain and potential role in fatty acid transport across human brain microvessel endothelial cells. J. Neurochem. 2011, 117, 735-746. [CrossRef] [PubMed]

74. Nguyen, L.N.; Ma, D.; Shui, G.; Wong, P.; Cazenave-Gassiot, A.; Zhang, X.; Wenk, M.R.; Goh, E.L.; Silver, D.L. Mfsd2a is a transporter for the essential omega-3 fatty acid docosahexaenoic acid. Nature 2014, 509, 503-506. [CrossRef] [PubMed]

75. Guemez-Gamboa, A.; Nguyen, L.N.; Yang, H.; Zaki, M.S.; Kara, M.; Ben-Omran, T.; Akizu, N.; Rosti, R.O.; Rosti, B.; Scott, E.; et al. Inactivating mutations in MFSD2A, required for omega-3 fatty acid transport in brain, cause a lethal microcephaly syndrome. Nat. Genet. 2015, 47, 809-813. [CrossRef] [PubMed]

76. Wong, B.H.; Silver, D.L. Mfsd2a: A physiologically important lysolipid transporter in the brain and eye. Adv. Exp. Med. Biol. 2020, 1276, 223-234. [CrossRef] [PubMed]

77. Sanchez-Campillo, M.; Ruiz-Palacios, M.; Ruiz-Alcaraz, A.J.; Prieto-Sanchez, M.T.; Blanco-Carnero, J.E.; Zornoza, M.; Ruiz-Pastor, M.J.; Demmelmair, H.; Sanchez-Solis, M.; Koletzko, B.; et al. Child head circumference and placental MFSD2a Expression are associated to the level of MFSD2a in maternal blood during pregnancy. Front. Endocrinol. 2020, 11, 38. [CrossRef]

78. Thies, F.; Delachambre, M.C.; Bentejac, M.; Lagarde, M.; Lecerf, J. Unsaturated fatty acids esterified in 2-acyl-1-lysophosphatidylcholine bound to albumin are more efficiently taken up by the young rat brain than the unesterified form. J. Neurochem. 1992, 59, 1110-1116. [CrossRef] [PubMed]

79. Chmurzynska, A. The multigene family of fatty acid-binding proteins (FABPs): Function, structure and polymorphism. J. Appl. Genet. 2006, 47, 39-48. [CrossRef]

80. Owada, Y.; Yoshimoto, T.; Kondo, H. Spatio-temporally differential expression of genes for three members of fatty acid binding proteins in developing and mature rat brains. J. Chem. Neuroanat. 1996, 12, 113-122. [CrossRef]

81. Cataltepe, O.; Arikan, M.C.; Ghelfi, E.; Karaaslan, C.; Ozsurekci, Y.; Dresser, K.; Li, Y.; Smith, T.W.; Cataltepe, S. Fatty acid binding protein 4 is expressed in distinct endothelial and non-endothelial cell populations in glioblastoma. Neuropathol. Appl. Neurobiol. 2012, 38, 400-410. [CrossRef]

82. Feng, L.; Hatten, M.E.; Heintz, N. Brain lipid-binding protein (BLBP): A novel signaling system in the developing mammalian CNS. Neuron 1994, 12, 895-908. [CrossRef]

83. Liang, Y.; Bollen, A.W.; Aldape, K.D.; Gupta, N. Nuclear FABP7 immunoreactivity is preferentially expressed in infiltrative glioma and is associated with poor prognosis in EGFR-overexpressing glioblastoma. BMC Cancer 2006, 6, 97. [CrossRef] [PubMed]

84. Kaloshi, G.; Mokhtari, K.; Carpentier, C.; Taillibert, S.; Lejeune, J.; Marie, Y.; Delattre, J.Y.; Godbout, R.; Sanson, M. FABP7 expression in glioblastomas: Relation to prognosis, invasion and EGFR status. J. Neurooncol. 2007, 84, 245-248. [CrossRef] [PubMed]

85. De Rosa, A.; Pellegatta, S.; Rossi, M.; Tunici, P.; Magnoni, L.; Speranza, M.C.; Malusa, F.; Miragliotta, V.; Mori, E.; Finocchiaro, G.; et al. A radial glia gene marker, fatty acid binding protein 7 (FABP7), is involved in proliferation and invasion of glioblastoma cells. PLoS ONE 2012, 7, e52113. [CrossRef]

86. Liu, R.Z.; Mita, R.; Beaulieu, M.; Gao, Z.; Godbout, R. Fatty acid binding proteins in brain development and disease. Int. J. Dev. Biol. 2010, 54, 1229-1239. [CrossRef] [PubMed] 
87. Bernlohr, D.A.; Coe, N.R.; Simpson, M.A.; Hertzel, A.V. Regulation of gene expression in adipose cells by polyunsaturated fatty acids. Adv. Exp. Med. Biol. 1997, 422, 145-156. [CrossRef]

88. Murphy, E.J.; Owada, Y.; Kitanaka, N.; Kondo, H.; Glatz, J.F. Brain arachidonic acid incorporation is decreased in heart fatty acid binding protein gene-ablated mice. Biochemistry 2005, 44, 6350-6360. [CrossRef]

89. Hanhoff, T.; Lucke, C.; Spener, F. Insights into binding of fatty acids by fatty acid binding proteins. Mol. Cell Biochem. 2002, 239, 45-54. [CrossRef]

90. Balendiran, G.K.; Schnutgen, F.; Scapin, G.; Borchers, T.; Xhong, N.; Lim, K.; Godbout, R.; Spener, F.; Sacchettini, J.C. Crystal structure and thermodynamic analysis of human brain fatty acid-binding protein. J. Biol. Chem. 2000, 275, 27045-27054. [CrossRef]

91. Owada, Y. Fatty acid binding protein: Localization and functional significance in the brain. Tohoku J. Exp. Med. 2008, 214, 213-220. [CrossRef]

92. Maximin, E.; Langelier, B.; Aioun, J.; Al-Gubory, K.H.; Bordat, C.; Lavialle, M.; Heberden, C. Fatty acid binding protein 7 and n-3 poly unsaturated fatty acid supply in early rat brain development. Dev. Neurobiol. 2016, 76, 287-297. [CrossRef]

93. Kawakita, E.; Hashimoto, M.; Shido, O. Docosahexaenoic acid promotes neurogenesis in vitro and in vivo. Neuroscience 2006, 139, 991-997. [CrossRef]

94. Sakayori, N.; Maekawa, M.; Numayama-Tsuruta, K.; Katura, T.; Moriya, T.; Osumi, N. Distinctive effects of arachidonic acid and docosahexaenoic acid on neural stem / progenitor cells. Genes Cells 2011, 16, 778-790. [CrossRef] [PubMed]

95. Cheon, M.S.; Kim, S.H.; Fountoulakis, M.; Lubec, G. Heart type fatty acid binding protein (H-FABP) is decreased in brains of patients with Down syndrome and Alzheimer's disease. J. Neural. Transm. Suppl. 2003, 225-234. [CrossRef]

96. Sanchez-Font, M.F.; Bosch-Comas, A.; Gonzalez-Duarte, R.; Marfany, G. Overexpression of FABP7 in Down syndrome fetal brains is associated with PKNOX1 gene-dosage imbalance. Nucleic Acids Res. 2003, 31, 2769-2777. [CrossRef] [PubMed]

97. Watanabe, A.; Toyota, T.; Owada, Y.; Hayashi, T.; Iwayama, Y.; Matsumata, M.; Ishitsuka, Y.; Nakaya, A.; Maekawa, M.; Ohnishi, T.; et al. Fabp7 maps to a quantitative trait locus for a schizophrenia endophenotype. PLoS Biol. 2007, 5, e297. [CrossRef] [PubMed]

98. Braff, D.L.; Geyer, M.A.; Light, G.A.; Sprock, J.; Perry, W.; Cadenhead, K.S.; Swerdlow, N.R. Impact of prepulse characteristics on the detection of sensorimotor gating deficits in schizophrenia. Schizophr. Res. 2001, 49, 171-178. [CrossRef]

99. Gearhart, D.A.; Toole, P.F.; Warren Beach, J. Identification of brain proteins that interact with 2-methylnorharman. An analog of the parkinsonian-inducing toxin, MPP+. Neurosci. Res. 2002, 44, 255-265. [CrossRef]

100. Steinacker, P.; Mollenhauer, B.; Bibl, M.; Cepek, L.; Esselmann, H.; Brechlin, P.; Lewczuk, P.; Poser, S.; Kretzschmar, H.A.; Wiltfang, J.; et al. Heart fatty acid binding protein as a potential diagnostic marker for neurodegenerative diseases. Neurosci. Lett. 2004, 370, 36-39. [CrossRef]

101. Mita, R.; Beaulieu, M.J.; Field, C.; Godbout, R. Brain fatty acid-binding protein and $\omega-3 / \omega-6$ fatty acids. J. Biol. Chem. 2010, 285, 37005-37015. [CrossRef]

102. Cunnane, S.C.; Plourde, M.; Pifferi, F.; Begin, M.; Feart, C.; Barberger-Gateau, P. Fish, docosahexaenoic acid and Alzheimer's disease. Prog. Lipid Res. 2009, 48, 239-256. [CrossRef]

103. Calderon, F.; Kim, H.Y. Docosahexaenoic acid promotes neurite growth in hippocampal neurons. J. Neurochem. 2004, 90, 979-988 [CrossRef] [PubMed]

104. Cao, D.; Xue, R.; Xu, J.; Liu, Z. Effects of docosahexaenoic acid on the survival and neurite outgrowth of rat cortical neurons in primary cultures. J. Nutr. Biochem. 2005, 16, 538-546. [CrossRef] [PubMed]

105. Insua, M.F.; Garelli, A.; Rotstein, N.P.; German, O.L.; Arias, A.; Politi, L.E. Cell cycle regulation in retinal progenitors by glia-derived neurotrophic factor and docosahexaenoic acid. Investig. Ophthalmol. Visual Sci. 2003, 44, 2235-2244. [CrossRef] [PubMed]

106. Aïd, S.; Vancassel, S.; Poumès-Ballihaut, C.; Chalon, S.; Guesnet, P.; Lavialle, M. Effect of a diet-induced n-3 PUFA depletion on cholinergic parameters in the rat hippocampus. J. Lipid Res. 2003, 44, 1545-1551. [CrossRef] [PubMed]

107. Chalon, S. Omega-3 fatty acids and monoamine neurotransmission. Prostaglandins Leukot. Essential Fatty Acids 2006, 75, 259-269. [CrossRef] [PubMed]

108. Anderson, G.J.; Neuringer, M.; Lin, D.S.; Connor, W.E. Can prenatal N-3 fatty acid deficiency be completely reversed after birth? Effects on retinal and brain biochemistry and visual function in rhesus monkeys. Pediatr. Res. 2005, 58, 865-872. [CrossRef]

109. Innis, S.M. Dietary (n-3) Fatty Acids and Brain Development. J. Nutr. 2018, 137, 855-859. [CrossRef]

110. Coti Bertrand, P.; O'Kusky, J.R.; Innis, S.M. Maternal dietary (n-3) fatty acid deficiency alters neurogenesis in the embryonic rat brain. J. Nutr. 2006, 136, 1570-1575. [CrossRef]

111. Salem, N.; Litman, B.; Kim, H.Y.; Gawrisch, K. Mechanisms of action of docosahexaenoic acid in the nervous system. Lipids 2001, 36, 945-959. [CrossRef]

112. Lengqvist, J.; Mata de Urquiza, A.; Bergman, A.-C.; Willson, T.M.; Sjövall, J.; Perlmann, T.; Griffiths, W.J. Polyunsaturated fatty acids including docosahexaenoic and arachidonic acid bind to the retinoid X receptor $\alpha$ ligand-binding domain. Mol. Cell Proteom. 2004, 3, 692-703. [CrossRef]

113. Rioux, L.; Arnold, S.E. The expression of retinoic acid receptor alpha is increased in the granule cells of the dentate gyrus in schizophrenia. Psychiatry Res. 2005, 133, 13-21. [CrossRef] 
114. Wada, K.; Nakajima, A.; Katayama, K.; Kudo, C.; Shibuya, A.; Kubota, N.; Terauchi, Y.; Tachibana, M.; Miyoshi, H.; Kamisaki, Y.; et al. Peroxisome proliferator-activated receptor $\gamma$-mediated regulation of neural stem cell proliferation and differentiation. J. Biol. Chem. 2006, 281, 12673-12681. [CrossRef]

115. Cao, D.H.; Xu, J.F.; Xue, R.H.; Zheng, W.F.; Liu, Z.L. Protective effect of chronic ethyl docosahexaenoate administration on brain injury in ischemic gerbils. Pharmacol. Biochem. Behav. 2004, 79, 651-659. [CrossRef] [PubMed]

116. Green, P.; Glozman, S.; Weiner, L.; Yavin, E. Enhanced free radical scavenging and decreased lipid peroxidation in the rat fetal brain after treatment with ethyl docosahexaenoate. Biochim. Biophys. Acta Mol. Cell Biol. Lipids 2001, 1532, 203-212. [CrossRef]

117. Okada, M.; Amamoto, T.; Tomonaga, M.; Kawachi, A.; Yazawa, K.; Mine, K.; Fujiwara, M. The chronic administration of docosahexaenoic acid reduces the spatial cognitive deficit following transient forebrain ischemia in rats. Neuroscience 1996, 71, 17-25. [CrossRef]

118. Samson, F.P.; Fabunmi, T.E.; Patrick, A.T.; Jee, D.; Gutsaeva, D.R.; Jahng, W.J. Fatty Acid Composition and Stoichiometry Determine the Angiogenesis Microenvironment. ACS Omega 2021, 6, 5953-5961. [CrossRef] [PubMed]

119. Wang, W.; Shinto, L.; Connor, W.E.; Quinn, J.F. Nutritional biomarkers in Alzheimer's disease: The association between carotenoids, n-3 fatty acids, and dementia severity. J. Alzheimers Dis. 2008, 13, 31-38. [CrossRef]

120. Cao, L.; Tan, L.; Wang, H.F.; Jiang, T.; Zhu, X.C.; Lu, H.; Tan, M.S.; Yu, J.T. Dietary patterns and risk of dementia: A systematic review and meta-analysis of cohort studies. Mol. Neurobiol. 2016, 53, 6144-6154. [CrossRef]

121. Bousquet, M.; Saint-Pierre, M.; Julien, C.; Salem, N., Jr.; Cicchetti, F.; Calon, F. Beneficial effects of dietary omega-3 polyunsaturated fatty acid on toxin-induced neuronal degeneration in an animal model of Parkinson's disease. FASEB J. 2008, 22, $1213-1225$. [CrossRef] [PubMed]

122. Sinn, N.; Milte, C.M.; Street, S.J.; Buckley, J.D.; Coates, A.M.; Petkov, J.; Howe, P.R. Effects of n-3 fatty acids, EPA v. DHA, on depressive symptoms, quality of life, memory and executive function in older adults with mild cognitive impairment: A 6-month randomised controlled trial. Br. J. Nutr. 2012, 107, 1682-1693. [CrossRef]

123. Freund-Levi, Y.; Eriksdotter-Jonhagen, M.; Cederholm, T.; Basun, H.; Faxen-Irving, G.; Garlind, A.; Vedin, I.; Vessby, B.; Wahlund, L.O.; Palmblad, J. Omega-3 fatty acid treatment in 174 patients with mild to moderate Alzheimer disease: OmegAD study: A randomized double-blind trial. Arch. Neurol. 2006, 63, 1402-1408. [CrossRef] [PubMed]

124. Quinn, J.F.; Raman, R.; Thomas, R.G.; Yurko-Mauro, K.; Nelson, E.B.; Van Dyck, C.; Galvin, J.E.; Emond, J.; Jack, C.R., Jr.; Weiner, M.; et al. Docosahexaenoic acid supplementation and cognitive decline in Alzheimer disease: A randomized trial. JAMA 2010, 304, 1903-1911. [CrossRef]

125. Eilander, A.; Hundscheid, D.C.; Osendarp, S.J.; Transler, C.; Zock, P.L. Effects of n-3 long chain polyunsaturated fatty acid supplementation on visual and cognitive development throughout childhood: A review of human studies. Prostaglandins Leukot. Essent. Fatty Acids 2007, 76, 189-203. [CrossRef]

126. Christie, W.W.; Harwood, J.L. Oxidation of polyunsaturated fatty acids to produce lipid mediators. Essays Biochem. 2020, 64, 401-421. [CrossRef]

127. Oh, D.Y.; Walenta, E.; Akiyama, T.E.; Lagakos, W.S.; Lackey, D.; Pessentheiner, A.R.; Sasik, R.; Hah, N.; Chi, T.J.; Cox, J.M.; et al. A Gpr120-selective agonist improves insulin resistance and chronic inflammation in obese mice. Nat. Med. 2014, 20,942-947. [CrossRef]

128. Diep, Q.N.; Touyz, R.M.; Schiffrin, E.L. Docosahexaenoic acid, a peroxisome proliferator-activated receptor-alpha ligand, induces apoptosis in vascular smooth muscle cells by stimulation of p38 mitogen-activated protein kinase. Hypertension 2000, 36, 851-855. [CrossRef]

129. Chitre, N.M.; Wood, B.J.; Ray, A.; Moniri, N.H.; Murnane, K.S. Docosahexaenoic acid protects motor function and increases dopamine synthesis in a rat model of Parkinson's disease via mechanisms associated with increased protein kinase activity in the striatum. Neuropharmacology 2020, 167, 107976. [CrossRef]

130. Zúñiga, J.; Cancino, M.; Medina, F.; Varela, P.; Vargas, R.; Tapia, G.; Videla, L.A.; Fernández, V. N-3 PUFA supplementation triggers PPAR- $\alpha$ activation and PPAR- $\alpha /$ NF- $\kappa B$ interaction: Anti-inflammatory implications in liver ischemia-reperfusion injury. PLoS ONE 2011, 6, e28502. [CrossRef]

131. Anderson, E.; Taylor, D. Stressing the heart of the matter: Re-thinking the mechanisms underlying therapeutic effects of $n-3$ polyunsaturated fatty acids. F1000 Med. Rep. 2012, 4, 13. [CrossRef]

132. Robertson, R.; Guihéneuf, F.; Schmid, M.; Stengel, D.; Fitzgerald, G.; Ross, P.; Stanton, C. Algae-Derived Polyunsaturated Fatty Acids: Implications for Human Health; Nova Sciences Publishers, Inc.: New York, NY, USA, 2013; p. 43.

133. Westphal, C.; Konkel, A.; Schunck, W.H. CYP-eicosanoids-A new link between omega-3 fatty acids and cardiac disease? Prostaglandins Other Lipid Mediat. 2011, 96, 99-108. [CrossRef]

134. Kuda, O. Bioactive metabolites of docosahexaenoic acid. Biochimie 2017, 136, 12-20. [CrossRef]

135. Serhan, C.N. Pro-resolving lipid mediators are leads for resolution physiology. Nature 2014, 510, 92-101. [CrossRef]

136. Bisicchia, E.; Sasso, V.; Catanzaro, G.; Leuti, A.; Besharat, Z.M.; Chiacchiarini, M.; Molinari, M.; Ferretti, E.; Viscomi, M.T.; Chiurchiù, V. Resolvin D1 halts remote neuroinflammation and improves functional recovery after focal brain damage via ALX/FPR2 receptor-regulated microRNAs. Mol. Neurobiol. 2018, 55, 6894-6905. [CrossRef]

137. Recchiuti, A.; Krishnamoorthy, S.; Fredman, G.; Chiang, N.; Serhan, C.N. MicroRNAs in resolution of acute inflammation: Identification of novel resolvin D1-miRNA circuits. FASEB J. 2010, 25, 544-560. [CrossRef] 
138. Zuo, G.; Zhang, D.; Mu, R.; Shen, H.; Li, X.; Wang, Z.; Li, H.; Chen, G. Resolvin D2 protects against cerebral ischemia/reperfusion injury in rats. Mol. Brain 2018, 11,1-13. [CrossRef]

139. Dalli, J.; Winkler, J.W.; Colas, R.A.; Arnardottir, H.; Cheng, C.Y.C.; Chiang, N.; Petasis, N.A.; Serhan, C.N. Resolvin D3 and aspirin-triggered resolvin D3 are potent immunoresolvents. Chem. Biol. 2013, 20, 188-201. [CrossRef]

140. Hong, S.; Tjonahen, E.; Morgan, E.L.; Lu, Y.; Serhan, C.N.; Rowley, A.F. Rainbow trout (Oncorhynchus mykiss) brain cells biosynthesize novel docosahexaenoic acid-derived resolvins and protectins-Mediator lipidomic analysis. Prostaglandins Other Lipid Mediat. 2005, 78, 107-116. [CrossRef]

141. Ariel, A.; Serhan, C.N. New lives given by cell death: Macrophage differentiation following their encounter with apoptotic leukocytes during the resolution of inflammation. Front. Immunol. 2012, 3, 4. [CrossRef]

142. Stables, M.J.; Shah, S.; Camon, E.B.; Lovering, R.C.; Newson, J.; Bystrom, J.; Farrow, S.; Gilroy, D.W. Transcriptomic analyses of murine resolution-phase macrophages. Blood 2011, 118, 192-208. [CrossRef]

143. Zhang, M.J.; Spite, M. Resolvins: Anti-inflammatory and proresolving mediators derived from omega-3 polyunsaturated fatty acids. Ann. Rev. Nutr. 2012, 32, 203-207. [CrossRef]

144. Serhan, C.N.; Dalli, J.; Colas, R.A.; Winkler, J.W.; Chiang, N. Protectins and maresins: New pro-resolving families of mediators in acute inflammation and resolution bioactive metabolome. Biochim. Biophys. Acta 2015, 1851, 397-413. [CrossRef]

145. Serhan, C.N.; Dalli, J.; Karamnov, S.; Choi, A.; Park, C.-K.; Xu, Z.-Z.; Ji, R.-R.; Zhu, M.; Petasis, N.A. Macrophage proresolving mediator maresin 1 stimulates tissue regeneration and controls pain. FASEB J. 2012, 26, 1755-1765. [CrossRef]

146. Serhan, C.N.; Yang, R.; Martinod, K.; Kasuga, K.; Pillai, P.S.; Porter, T.F.; Oh, S.F.; Spite, M. Maresins: Novel macrophage mediators with potent antiinflammatory and proresolving actions. J. Exp. Med. 2008, 206, 15-23. [CrossRef]

147. Yanes, O.; Clark, J.; Wong, D.M.; Patti, G.J.; Sánchez-Ruiz, A.; Benton, H.P.; Trauger, S.A.; Desponts, C.; Ding, S.; Siuzdak, G. Metabolic oxidation regulates embryonic stem cell differentiation. Nat. Chem. Biol. 2010, 6, 411-417. [CrossRef]

148. Yang, T.; Xu, G.; Newton, P.T.; Chagin, A.S.; Mkrtchian, S.; Carlström, M.; Zhang, X.M.; Harris, R.A.; Cooter, M.; Berger, M.; et al. Maresin 1 attenuates neuroinflammation in a mouse model of perioperative neurocognitive disorders. Br. J. Anaesth. 2019, 122, 350-360. [CrossRef]

149. Francos-Quijorna, I.; Santos-Nogueira, E.; Gronert, K.; Sullivan, A.B.; Kopp, M.A.; Brommer, B.; David, S.; Schwab, J.M.; LópezVales, R. Maresin 1 promotes inflammatory resolution, neuroprotection, and functional neurological recovery after spinal cord injury. J. Neurosci. 2017, 37, 11731-11743. [CrossRef]

150. Chiang, N.; Libreros, S.; Norris, P.C.; de la Rosa, X.; Serhan, C.N. Maresin 1 activates LGR6 receptor promoting phagocyte immunoresolvent functions. J. Clin. Investig. 2019, 129, 5294-5311. [CrossRef]

151. Bazan, N.G.; Molina, M.F.; Gordon, W.C. Docosahexaenoic acid signalolipidomics in nutrition: Significance in aging, neuroinflammation, macular degeneration, Alzheimer's, and other neurodegenerative diseases. Ann. Rev. Nutr. 2011, 31, 321-351. [CrossRef]

152. Balas, L.; Durand, T. Dihydroxylated E, E, Z-docosatrienes. An overview of their synthesis and biological significance. Prog. Lipid Res. 2016, 61, 1-18. [CrossRef]

153. Bazan, N.G. Neuroprotectin D1 (NPD1): A DHA-derived mediator that protects brain and retina against cell injury-induced oxidative stress. Brain Pathol. 2005, 15, 15267-15278. [CrossRef]

154. Calandria, J.M.; Marcheselli, V.L.; Mukherjee, P.K.; Uddin, J.; Winkler, J.W.; Petasis, N.A.; Bazan, N.G. Selective survival rescue in 15-lipoxygenase-1-deficient retinal pigment epithelial cells by the novel docosahexaenoic acid-derived mediator, neuroprotectin D1. J. Biol. Chem. 2009, 284, 17877-17882. [CrossRef]

155. Morita, M.; Kuba, K.; Ichikawa, A.; Nakayama, M.; Katahira, J.; Iwamoto, R.; Watanebe, T.; Sakabe, S.; Daidoji, T.; Nakamura, S.; et al. The lipid mediator protectin D1 inhibits influenza virus replication and improves severe influenza. Cell 2013, 153, 112-125. [CrossRef]

156. Zhao, Y.; Calon, F.; Julien, C.; Winkler, J.W.; Petasis, N.A.; Lukiw, W.J.; Bazan, N.G. Docosahexaenoic acid-derived neuroprotectin D1 induces neuronal survival via secretase- and PPAR $\gamma$-mediated mechanisms in Alzheimer's disease models. PLoS ONE 2011, 6, e15816. [CrossRef] [PubMed]

157. Garcia-Sastre, A. Lessons from lipids in the fight against influenza. Cell 2013, 154, 22-23. [CrossRef] [PubMed]

158. Gladine, C.; Laurie, J.-C.; Giulia, C.; Dominique, B.; Corinne, C.; Nathalie, H.; Bart, S.; Giuseppe, Z.; Alessio, P.; Jean-Marie, G.; et al. Neuroprostanes, produced by free-radical mediated peroxidation of DHA, inhibit the inflammatory response of human macrophages. Free Radic. Biol. Med. 2014, 75, S15-S25. [CrossRef] [PubMed]

159. Groeger, A.L.; Cipollina, C.; Cole, M.P.; Woodcock, S.R.; Bonacci, G.; Rudolph, T.K.; Rudolph, V.; Freeman, B.A.; Schopfer, F.J. Cyclooxygenase-2 generates anti-inflammatory mediators from omega-3 fatty acids. Nat. Chem. Biol. 2010, 6, 433-441. [CrossRef] [PubMed]

160. Dyall, S.C. Long-chain omega-3 fatty acids and the brain: A review of the independent and shared effects of EPA, DPA and DHA. Front Aging Neurosci. 2015, 7, 52. [CrossRef]

161. De Petrocellis, L.; Melck, D.; Bisogno, T.; Milone, A.; Di Marzo, V. Finding of the endocannabinoid signalling system in Hydra, a very primitive organism: Possible role in the feeding response. Neuroscience 1999, 92, 377-387. [CrossRef]

162. Kim, J.; Carlson, M.E.; Watkins, B.A. Docosahexaenoyl ethanolamide improves glucose uptake and alters endocannabinoid system gene expression in proliferating and differentiating C2C12 myoblasts. Front. Physiol. 2014, 5. [CrossRef] 
163. Soderstrom, K. Endocannabinoids link feeding state and auditory perception-related gene expression. J. Neurosci. 2004, 24, 10013-10024. [CrossRef]

164. Valenti, M.; Cottone, E.; Martinez, R.; De Pedro, N.; Rubio, M.; Viveros, M.P.; Franzoni, M.F.; Delgado, M.J.; Di Marzo, V. The endocannabinoid system in the brain of Carassius auratus and its possible role in the control of food intake. J. Neurochem. 2005, 95, 662-672. [CrossRef]

165. Chiang, N.; Takano, T.; Arita, M.; Watanabe, S.; Serhan, C.N. A novel rat lipoxin A4 receptor that is conserved in structure and function. Br. J. Pharmacol. 2003, 139, 89-98. [CrossRef]

166. Piazza, P.V.; Lafontan, M.; Girard, J. Integrated physiology and pathophysiology of CB1-mediated effects of the endocannabinoid system. Diabetes Metab. 2007, 33, 97-107. [CrossRef]

167. Masoodi, M.; Kuda, O.; Rossmeisl, M.; Flachs, P.; Kopecky, J. Lipid signaling in adipose tissue: Connecting inflammation \& metabolism. Biochim. Biophys. Acta Mol. Cell Biol. Lipids 2015, 1851, 503-518.

168. D'Addario, C.; Micioni Di Bonaventura, M.V.; Pucci, M.; Romano, A.; Gaetani, S.; Ciccocioppo, R.; Cifani, C.; Maccarrone, M. Endocannabinoid signaling and food addiction. Neurosci. Biobehav. Rev. 2014, 47, 203-224. [CrossRef] [PubMed]

169. Wagner, J.J.; Alger, B.E. Increased neuronal excitability during depolarization-induced suppression of inhibition in rat hippocampus. J. Physiol. 1996, 495, 107-112. [CrossRef]

170. Wilson, R.I.; Nicoll, R.A. Neuroscience: Endocannabinoid signaling in the brain. Science 2002, 296, 678-682. [CrossRef] [PubMed]

171. Calder, P.C. Omega-3 polyunsaturated fatty acids and inflammatory processes: Nutrition or pharmacology? Br. J. Clin. Pharmacol. 2013, 75, 645-662. [CrossRef] [PubMed]

172. Lu, H.C.; MacKie, K. An introduction to the endogenous cannabinoid system. Biol. Psychiatry 2016. [CrossRef]

173. Song, C.; Manku, M.S.; Horrobin, D.F. Long-chain polyunsaturated fatty acids modulate interleukin- $1 \beta$-induced changes in behavior, monoaminergic neurotransmitters, and brain inflammation in rats. J. Nutr. 2018. [CrossRef] [PubMed]

174. Bozzatello, P.; Brignolo, E.; De Grandi, E.; Bellino, S. Supplementation with omega-3 fatty acids in psychiatric disorders: A review of literature data. J. Clin. Med. 2016, 5, 67. [CrossRef]

175. Hibbeln, J.R. Fish consumption and major depression. Lancet 1998, 351, 1213. [CrossRef]

176. Kiliaan, A.; Königs, A. Critical appraisal of omega-3 fatty acids in attention-deficit/hyperactivity disorder treatment. Neuropsychiatr. Dis. Treat. 2016, 12, 1869-1882. [CrossRef] [PubMed]

177. Lukiw, W.J.; Cui, J.G.; Marcheselli, V.L.; Bodker, M.; Botkjaer, A.; Gotlinger, K.; Serhan, C.N.; Bazan, N.G. A role for docosahexaenoic acid-derived neuroprotectin D1 in neural cell survival and Alzheimer disease. J. Clin. Investig. 2005, 115, 2774-2783. [CrossRef]

178. Boudrault, C.; Bazinet, R.P.; Ma, D.W.L. Experimental models and mechanisms underlying the protective effects of $\mathrm{n}-3$ polyunsaturated fatty acids in Alzheimer's disease. J. Nutr. Biochem. 2009, 20, 1-10. [CrossRef]

179. Hashimoto, M.; Hossain, S.; Agdul, H.; Shido, O. Docosahexaenoic acid-induced amelioration on impairment of memory learning in amyloid $\beta$-infused rats relates to the decreases of amyloid $\beta$ and cholesterol levels in detergent-insoluble membrane fractions. Biochim. Biophys. Acta Mol. Cell Biol. Lipids 2005, 1738, 91-98. [CrossRef]

180. Seidl, S.E.; Santiago, J.A.; Bilyk, H.; Potashkin, J.A. The emerging role of nutrition in Parkinson's disease. Front. Aging Neurosci. 2014, 6. [CrossRef] [PubMed]

181. McNamara, R.K. DHA Deficiency and prefrontal cortex neuropathology in recurrent affective disorders. J. Nutr. 2010, 140, 864-868. [CrossRef] [PubMed]

182. McNamara, R.K.; Hahn, C.G.; Jandacek, R.; Rider, T.; Tso, P.; Stanford, K.E.; Richtand, N.M. Selective deficits in the omega-3 fatty acid docosahexaenoic acid in the postmortem orbitofrontal cortex of patients with major depressive disorder. Biol. Psychiatry 2007, 62, 17-24. [CrossRef] [PubMed]

183. Basak, S.; Vilasagaram, S.; Duttaroy, A.K. Maternal dietary deficiency of n-3 fatty acids affects metabolic and epigenetic phenotypes of the developing fetus. Prostaglandins Leukot. Essent. Fatty Acids 2020, 158, 102109. [CrossRef]

184. Srinivas, V.; Molangiri, A.; Mallepogu, A.; Kona, S.R.; Ibrahim, A.; Duttaroy, A.K.; Basak, S. Maternal n-3 PUFA deficiency alters uterine artery remodeling and placental epigenome in the mice. J. Nutr. Biochem. 2021, in press. [CrossRef]

185. Boucher, O.; Burden, M.J.; Muckle, G.; Saint-Amour, D.; Ayotte, P.; Dewailly, E.; Nelson, C.A.; Jacobson, S.W.; Jacobson, J.L. Neurophysiologic and neurobehavioral evidence of beneficial effects of prenatal omega-3 fatty acid intake on memory function at school age. Am. J. Clin. Nutr. 2011, 93, 1025-1037. [CrossRef]

186. Mulder, K.A.; King, D.J.; Innis, S.M. Omega-3 fatty acid deficiency in infants before birth identified using a randomized trial of maternal DHA supplementation in pregnancy. PLoS ONE 2014, 9, e83764. [CrossRef]

187. Bos, D.J.; Oranje, B.; Veerhoek, E.S.; Van Diepen, R.M.; Weusten, J.M.H.; Demmelmair, H.; Koletzko, B.; De Sain-Van Der Velden, M.G.M.; Eilander, A.; Hoeksma, M.; et al. Reduced symptoms of inattention after dietary omega-3 fatty acid supplementation in boys with and without attention deficit/hyperactivity disorder. Neuropsychopharmacology 2015, 40, 2298-2306. [CrossRef]

188. Parellada, M.; Llorente, C.; Calvo, R.; Gutierrez, S.; Lázaro, L.; Graell, M.; Guisasola, M.; Dorado, M.L.; Boada, L.; Romo, J.; et al. Randomized trial of omega-3 for autism spectrum disorders: Effect on cell membrane composition and behavior. Eur. Neuropsychopharmacol. 2017, 27, 1319-1330. [CrossRef] [PubMed]

189. Bauer, I.; Hughes, M.; Rowsell, R.; Cockerell, R.; Pipingas, A.; Crewther, S.; Crewther, D. Omega-3 supplementation improves cognition and modifies brain activation in young adults. Hum. Psychopharmacol. 2014, 29, 133-144. [CrossRef] [PubMed] 
190. Jaremka, L.M.; Derry, H.M.; Bornstein, R.; Prakash, R.S.; Peng, J.; Belury, M.A.; Andridge, R.R.; Malarkey, W.B.; Kiecolt-Glaser, J.K. Omega-3 supplementation and loneliness-related memory problems: Secondary analyses of a randomized controlled trial. Psychosom. Med. 2014, 76, 650-658. [CrossRef]

191. Smith, S.L.; Rouse, C.A. Docosahexaenoic acid and the preterm infant. Mater. Health Neonatol. Perinatol. 2017, 3, 22. [CrossRef]

192. Albanese, E.; Dangour, A.D.; Uauy, R.; Acosta, D.; Guerra, M.; Guerra, S.S.; Huang, Y.; Jacob, K.S.; de Rodriguez, J.L.; Noriega, L.H.; et al. Dietary fish and meat intake and dementia in Latin America, China, and India: A 10/66 Dementia Research Group population-based study. Am. J. Clin. Nutr. 2009, 90, 392-400. [CrossRef] [PubMed]

193. Milte, C.M.; Sinn, N.; Street, S.J.; Buckley, J.D.; Coates, A.M.; Howe, P.R. Erythrocyte polyunsaturated fatty acid status, memory, cognition and mood in older adults with mild cognitive impairment and healthy controls. Prostaglandins Leukot. Essent. Fatty Acids 2011, 84, 153-161. [CrossRef]

194. Yin, Y.; Fan, Y.; Lin, F.; Xu, Y.; Zhang, J. Nutrient biomarkers and vascular risk factors in subtypes of mild cognitive impairment: A cross-sectional study. J. Nutr. Health Aging. 2015, 19, 39-47. [CrossRef]

195. Bazinet, R.P.; Layé, S. Polyunsaturated fatty acids and their metabolites in brain function and disease. Nat. Rev. Neurosci. 2014, 15, 771-785. [CrossRef]

196. Shamim, A.; Mahmood, T.; Ahsan, F.; Kumar, A.; Bagga, P. Lipids: An insight into the neurodegenerative disorders. Clin. Nutr Exp. 2018, 20, 1-19. [CrossRef]

197. Lopez, L.B.; Kritz-Silverstein, D.; Barrett Connor, E. High dietary and plasma levels of the omega-3 fatty acid docosahexaenoic acid are associated with decreased dementia risk: The Rancho Bernardo study. J. Nutr. Health Aging. 2011, 15, 25-31. [CrossRef]

198. Phillips, M.A.; Childs, C.E.; Calder, P.C.; Rogers, P.J. Lower omega-3 fatty acid intake and status are associated with poorer cognitive function in older age: A comparison of individuals with and without cognitive impairment and Alzheimer's disease. Nutr. Neurosci. 2012, 15, 271-277. [CrossRef] [PubMed]

199. Schaefer, E.J.; Bongard, V.; Beiser, A.S.; Lamon-Fava, S.; Robins, S.J.; Au, R.; Tucker, K.L.; Kyle, D.J.; Wilson, P.W.; Wolf, P.A. Plasma phosphatidylcholine docosahexaenoic acid content and risk of dementia and Alzheimer disease: The Framingham Heart Study. Arch. Neurol. 2006, 63, 1545-1550. [CrossRef] [PubMed]

200. Shatenstein, B.; Kergoat, M.J.; Reid, I. Poor nutrient intakes during 1-year follow-up with community-dwelling older adults with early-stage Alzheimer dementia compared to cognitively intact matched controls. J. Am. Diet Assoc. 2007, 107, 2091-2099. [CrossRef]

201. Kotani, S.; Sakaguchi, E.; Warashina, S.; Matsukawa, N.; Ishikura, Y.; Kiso, Y.; Sakakibara, M.; Yoshimoto, T.; Guo, J.; Yamashima, T. Dietary supplementation of arachidonic and docosahexaenoic acids improves cognitive dysfunction. Neurosci. Res. 2006, 56, 159-164. [CrossRef] [PubMed]

202. Wurtman, R.J.; Ulus, I.H.; Cansev, M.; Watkins, C.J.; Wang, L.; Marzloff, G. Synaptic proteins and phospholipids are increased in gerbil brain by administering uridine plus docosahexaenoic acid orally. Brain Res. 2006, 1088, 83-92. [CrossRef]

203. Gomez-Soler, M.; Cordobilla, B.; Morato, X.; Fernandez-Duenas, V.; Domingo, J.C.; Ciruela, F. Triglyceride Form of Docosahexaenoic Acid Mediates Neuroprotection in Experimental Parkinsonism. Front. Neurosci. 2018, 12, 604. [CrossRef] [PubMed]

204. Patrick, R.P.; Ames, B.N. Vitamin D and the omega-3 fatty acids control serotonin synthesis and action, part 2: Relevance for ADHD, bipolar disorder, schizophrenia, and impulsive behavior. FASEB J. 2015, 29, 2207-2222. [CrossRef]

205. McNamara, R.K.; Jandacek, R.; Rider, T.; Tso, P.; Hahn, C.G.; Richtand, N.M.; Stanford, K.E. Abnormalities in the fatty acid composition of the postmortem orbitofrontal cortex of schizophrenic patients: Gender differences and partial normalization with antipsychotic medications. Schizophr. Res. 2007, 91, 37-50. [CrossRef]

206. Sinn, N.; Bryan, J. Effect of supplementation with polyunsaturated fatty acids and micronutrients on learning and behavior problems associated with child ADHD. J. Dev. Behav. Pediatr. 2007, 28, 82-91. [CrossRef]

207. Sinn, N.; Bryan, J.; Wilson, C. Cognitive effects of polyunsaturated fatty acids in children with attention deficit hyperactivity disorder symptoms: A randomised controlled trial. Prostaglandins Leukot. Essent. Fatty Acids 2008, 78, 311-326. [CrossRef] [PubMed]

208. Belanger, S.A.; Vanasse, M.; Spahis, S.; Sylvestre, M.P.; Lippe, S.; L'Heureux, F.; Ghadirian, P.; Vanasse, C.M.; Levy, E. Omega-3 fatty acid treatment of children with attention-deficit hyperactivity disorder: A randomized, double-blind, placebo-controlled study. Paediatr. Child Health 2009, 14, 89-98. [CrossRef]

209. Johnson, M.; Ostlund, S.; Fransson, G.; Kadesjo, B.; Gillberg, C. Omega-3/omega-6 fatty acids for attention deficit hyperactivity disorder: A randomized placebo-controlled trial in children and adolescents. J. Atten. Disord. 2009, 12, 394-401. [CrossRef] [PubMed]

210. Gustafsson, P.A.; Birberg-Thornberg, U.; Duchen, K.; Landgren, M.; Malmberg, K.; Pelling, H.; Strandvik, B.; Karlsson, T. EPA supplementation improves teacher-rated behaviour and oppositional symptoms in children with ADHD. Acta Paediatr. 2010, 99, 1540-1549. [CrossRef]

211. Hariri, M.; Djazayery, A.; Djalali, M.; Saedisomeolia, A.; Rahimi, A.; Abdolahian, E. Effect of n-3 supplementation on hyperactivity, oxidative stress and inflammatory mediators in children with attention-deficit-hyperactivity disorder. Malays J. Nutr. 2012, 18, 329-335.

212. Behdani, F.; Hebrani, P.; Naseraee, A.; Haghighi, M.B.; Akhavanrezayat, A. Does omega-3 supplement enhance the therapeutic results of methylphenidate in attention deficit hyperactivity disorder patients? J. Res. Med. Sci. 2013, 18, 653-658. [PubMed] 
213. Dashti, N.; Hekmat, H.; Soltani, H.R.; Rahimdel, A.; Javaherchian, M. Comparison of therapeutic effects of omega-3 and methylphenidate (ritalin $((\mathrm{R})))$ in treating children with attention deficit hyperactivity disorder. Iran J. Psychiatry Behav. Sci. 2014, 8, 7-11.

214. Anand, P.; Sachdeva, A. Effect of poly unsaturated fatty acids administration on children with attention deficit hyperactivity disorder: A randomized controlled trial. J. Clin. Diagn. Res. 2016, 10, OC01-OC05. [CrossRef] [PubMed]

215. Assareh, M.; Davari Ashtiani, R.; Khademi, M.; Jazayeri, S.; Rai, A.; Nikoo, M. Efficacy of Polyunsaturated Fatty Acids (PUFA) in the treatment of attention deficit hyperactivity disorder. J. Atten. Disord. 2017, 21, 78-85. [CrossRef]

216. Kean, J.D.; Sarris, J.; Scholey, A.; Silberstein, R.; Downey, L.A.; Stough, C. Reduced inattention and hyperactivity and improved cognition after marine oil extract (PCSO-524(R)) supplementation in children and adolescents with clinical and subclinical symptoms of attention-deficit hyperactivity disorder (ADHD): A randomised, double-blind, placebo-controlled trial. Psychopharmacology 2017, 234, 403-420. [CrossRef] [PubMed]

217. Voigt, R.G.; Llorente, A.M.; Jensen, C.L.; Fraley, J.K.; Berretta, M.C.; Heird, W.C. A randomized, double-blind, placebo-controlled trial of docosahexaenoic acid supplementation in children with attention-deficit/hyperactivity disorder. J. Pediatr. 2001, 139, 189-196. [CrossRef] [PubMed]

218. Amminger, G.P.; Schafer, M.R.; Papageorgiou, K.; Klier, C.M.; Cotton, S.M.; Harrigan, S.M.; Mackinnon, A.; McGorry, P.D.; Berger, G.E. Long-chain omega-3 fatty acids for indicated prevention of psychotic disorders: A randomized, placebo-controlled trial. Arch. Gen. Psychiatry 2010, 67, 146-154. [CrossRef]

219. Pawelczyk, T.; Grancow-Grabka, M.; Kotlicka-Antczak, M.; Trafalska, E.; Pawelczyk, A. A randomized controlled study of the efficacy of six-month supplementation with concentrated fish oil rich in omega-3 polyunsaturated fatty acids in first episode schizophrenia. J. Psychiatr Res. 2016, 73, 34-44. [CrossRef]

220. Ammann, E.M.; Pottala, J.V.; Harris, W.S.; Espeland, M.A.; Wallace, R.; Denburg, N.L.; Carnahan, R.M.; Robinson, J.G. omega-3 fatty acids and domain-specific cognitive aging: Secondary analyses of data from WHISCA. Neurology 2013, 81, $1484-1491$. [CrossRef]

221. Maekawa, M.; Watanabe, A.; Iwayama, Y.; Kimura, T.; Hamazaki, K.; Balan, S.; Ohba, H.; Hisano, Y.; Nozaki, Y.; Ohnishi, T.; et al. Polyunsaturated fatty acid deficiency during neurodevelopment in mice models the prodromal state of schizophrenia through epigenetic changes in nuclear receptor genes. Transl. Psychiatry 2017, 7, e1229. [CrossRef]

222. McNamara, R.K.; Jandacek, R.; Tso, P.; Blom, T.J.; Welge, J.A.; Strawn, J.R.; Adler, C.M.; Strakowski, S.M.; DelBello, M.P. Adolescents with or at ultra-high risk for bipolar disorder exhibit erythrocyte docosahexaenoic acid and eicosapentaenoic acid deficits: A candidate prodromal risk biomarker. Early Interv. Psychiatry 2016, 10, 203-211. [CrossRef]

223. Stoll, A.L.; Severus, W.E.; Freeman, M.P.; Rueter, S.; Zboyan, H.A.; Diamond, E.; Cress, K.K.; Marangell, L.B. Omega 3 fatty acids in bipolar disorder: A preliminary double-blind, placebo-controlled trial. Arch. Gen. Psychiatry 1999, 56, 407-412. [CrossRef] [PubMed]

224. Chiu, C.C.; Huang, S.Y.; Chen, C.C.; Su, K.P. Omega-3 fatty acids are more beneficial in the depressive phase than in the manic phase in patients with bipolar I disorder. J. Clin. Psychiatry 2005, 66, 1613-1614. [CrossRef] [PubMed]

225. Clayton, E.H.; Hanstock, T.L.; Hirneth, S.J.; Kable, C.J.; Garg, M.L.; Hazell, P.L. Reduced mania and depression in juvenile bipolar disorder associated with long-chain omega-3 polyunsaturated fatty acid supplementation. Eur. J. Clin. Nutr. 2009, 63, 1037-1040. [CrossRef] [PubMed]

226. Meldrum, S.J.; D'Vaz, N.; Simmer, K.; Dunstan, J.A.; Hird, K.; Prescott, S.L. Effects of high-dose fish oil supplementation during early infancy on neurodevelopment and language: A randomised controlled trial. Br. J. Nutr. 2012, 108, 1443-1454. [CrossRef]

227. Birch, E.E.; Garfield, S.; Castaneda, Y.; Hughbanks-Wheaton, D.; Uauy, R.; Hoffman, D. Visual acuity and cognitive outcomes at 4 years of age in a double-blind, randomized trial of long-chain polyunsaturated fatty acid-supplemented infant formula. Early Hum. Dev. 2007, 83, 279-284. [CrossRef]

228. Osendarp, S.J.; Baghurst, K.I.; Bryan, J.; Calvaresi, E.; Hughes, D.; Hussaini, M.; Karyadi, S.J.; van Klinken, B.J.; van der Knaap, H.C.; Lukito, W.; et al. Effect of a 12-mo micronutrient intervention on learning and memory in well-nourished and marginally nourished school-aged children: 2 parallel, randomized, placebo-controlled studies in Australia and Indonesia. Am. J. Clin. Nutr. 2007, 86, 1082-1093. [CrossRef]

229. Richardson, A.J.; Burton, J.R.; Sewell, R.P.; Spreckelsen, T.F.; Montgomery, P. Docosahexaenoic acid for reading, cognition and behavior in children aged 7-9 years: A randomized, controlled trial (the DOLAB Study). PLoS ONE 2012, 7, e43909. [CrossRef]

230. Dalton, A.; Wolmarans, P.; Witthuhn, R.C.; van Stuijvenberg, M.E.; Swanevelder, S.A.; Smuts, C.M. A randomised control trial in schoolchildren showed improvement in cognitive function after consuming a bread spread, containing fish flour from a marine source. Prostaglandins Leukot. Essent. Fatty Acids 2009, 80, 143-149. [CrossRef]

231. Brew, B.K.; Toelle, B.G.; Webb, K.L.; Almqvist, C.; Marks, G.B.; investigators, C. Omega-3 supplementation during the first 5 years of life and later academic performance: A randomised controlled trial. Eur. J. Clin. Nutr. 2015, 69, 419-424. [CrossRef]

232. Lassek, W.D.; Gaulin, S.J. Sex differences in the relationship of dietary Fatty acids to cognitive measures in american children. Front. Evol. Neurosci. 2011, 3, 5. [CrossRef]

233. Shulkin, M.; Pimpin, L.; Bellinger, D.; Kranz, S.; Fawzi, W.; Duggan, C.; Mozaffarian, D. N-3 fatty acid supplementation in mothers, preterm infants, and term infants and childhood psychomotor and visual development: A systematic review and meta-analysis. J. Nutr. 2018, 149, 409-418. [CrossRef] [PubMed] 
234. Colombo, J.; Shaddy, D.J.; Gustafson, K.; Gajewski, B.J.; Thodosoff, J.M.; Kerling, E.; Carlson, S.E. The Kansas University DHA Outcomes Study (KUDOS) clinical trial: Long-term behavioral follow-up of the effects of prenatal DHA supplementation. Am. J. Clin. Nutr. 2019, 109, 1380-1392. [CrossRef]

235. Keim, S.A.; Boone, K.M.; Klebanoff, M.A.; Turner, A.N.; Rausch, J.; Nelin, M.A.; Rogers, L.K.; Yeates, K.O.; Nelin, L.; Sheppard, K.W. Effect of docosahexaenoic add supplementation vs placebo on developmental outcomes of toddlers born preterm a randomized clinical. JAMA Pediatr. 2018, 172, 1126-1134. [CrossRef]

236. Makrides, M.; Gibson, R.A.; McPhee, A.J.; Yelland, L.; Quinlivan, J.; Ryan, P.; Doyle, L.W.; Anderson, P.; Else, P.L.; Meyer, B.J.; et al. Effect of DHA supplementation during pregnancy on maternal depression and neurodevelopment of young children: A randomized controlled trial. JAMA J. Am. Med. Assoc. 2010, 304, 1675-1683. [CrossRef]

237. Collins, C.T.; Gibson, R.A.; Anderson, P.J.; McPhee, A.J.; Sullivan, T.R.; Gould, J.F.; Ryan, P.; Doyle, L.W.; Davis, P.G.; McMichael, J.E.; et al. Neurodevelopmental outcomes at 7 years' corrected age in preterm infants who were fed high-dose docosahexaenoic acid to term equivalent: A follow-up of a randomised controlled trial. BMJ Open 2015, 5. [CrossRef] [PubMed]

238. Smithers, L.G.; Collins, C.T.; Simmonds, L.A.; Gibson, R.A.; McPhee, A.; Makrides, M. Feeding preterm infants milk with a higher dose of docosahexaenoic acid than that used in current practice does not influence language or behavior in early childhood: A follow-up study of a randomized controlled trial. Am. J. Clin. Nutr. 2010, 91, 628-634. [CrossRef] [PubMed]

239. Basak, S.; Duttaroy, A.K. Effects of fatty acids on angiogenic activity in the placental extravillious trophoblast cells. Prostaglandins Leukot. Essent. Fatty Acids 2013, 88, 155-162. [CrossRef] [PubMed]

240. Bosetti, F. Arachidonic acid metabolism in brain physiology and pathology: Lessons from genetically altered mouse models. J. Neurochem. 2007, 102, 577-586. [CrossRef] [PubMed]

241. Harauma, A.; Hatanaka, E.; Yasuda, H.; Nakamura, M.T.; Salem, N., Jr.; Moriguchi, T. Effects of arachidonic acid, eicosapentaenoic acid and docosahexaenoic acid on brain development using artificial rearing of delta-6-desaturase knockout mice. Prostaglandins Leukot. Essent. Fatty Acids 2017, 127, 32-39. [CrossRef]

242. Contreras, M.A.; Greiner, R.S.; Chang, M.C.; Myers, C.S.; Salem, N., Jr.; Rapoport, S.I. Nutritional deprivation of alpha-linolenic acid decreases but does not abolish turnover and availability of unacylated docosahexaenoic acid and docosahexaenoyl-CoA in rat brain. J. Neurochem. 2000, 75, 2392-2400. [CrossRef] [PubMed]

243. Coronary heart disease in seven countries. Summary. Circulation 1970, 41, I186-I195.

244. Sun, G.Y.; Shelat, P.B.; Jensen, M.B.; He, Y.; Sun, A.Y.; Simonyi, A. Phospholipases A2 and inflammatory responses in the central nervous system. Neuromolecular. Med. 2010, 12, 133-148. [CrossRef]

245. Bazinet, R.P. Is the brain arachidonic acid cascade a common target of drugs used to manage bipolar disorder? Biochem. Soc. Trans. 2009, 37, 1104-1109. [CrossRef]

246. Rapoport, S.I. Arachidonic acid and the brain. J. Nutr. 2008, 138, 2515-2520. [CrossRef]

247. Duncan, R.E.; Bazinet, R.P. Brain arachidonic acid uptake and turnover: Implications for signaling and bipolar disorder. Curr. Opin. Clin. Nutr. Metab. Care 2010, 13, 130-138. [CrossRef] [PubMed]

248. Fraser, T.; Tayler, H.; Love, S. Fatty acid composition of frontal, temporal and parietal neocortex in the normal human brain and in Alzheimer's disease. Neurochem. Res. 2010, 35, 503-513. [CrossRef] [PubMed]

249. Hosono, T.; Mouri, A.; Nishitsuji, K.; Jung, C.G.; Kontani, M.; Tokuda, H.; Kawashima, H.; Shibata, H.; Suzuki, T.; Nabehsima, T.; et al. Arachidonic or docosahexaenoic acid diet prevents memory impairment in Tg2576 mice. J. Alzheimers Dis. 2015, 48, 149-162. [CrossRef]

250. Hosono, T.; Nishitsuji, K.; Nakamura, T.; Jung, C.G.; Kontani, M.; Tokuda, H.; Kawashima, H.; Kiso, Y.; Suzuki, T.; Michikawa, M. Arachidonic acid diet attenuates brain Abeta deposition in Tg2576 mice. Brain Res. 2015, 1613, 92-99. [CrossRef]

251. Katsuki, H.; Okuda, S. Arachidonic acid as a neurotoxic and neurotrophic substance. Prog. Neurobiol. 1995, 46, 607-636. [CrossRef]

252. Sanchez-Mejia, R.O.; Newman, J.W.; Toh, S.; Yu, G.Q.; Zhou, Y.; Halabisky, B.; Cisse, M.; Scearce-Levie, K.; Cheng, I.H.; Gan, L.; et al. Phospholipase A2 reduction ameliorates cognitive deficits in a mouse model of Alzheimer's disease. Nat. Neurosci. 2008, 11, 1311-1318. [CrossRef] [PubMed]

253. Vijayaraghavan, S.; Huang, B.; Blumenthal, E.M.; Berg, D.K. Arachidonic acid as a possible negative feedback inhibitor of nicotinic acetylcholine receptors on neurons. J. Neurosci. 1995, 15, 3679-3687. [CrossRef]

254. Williams, J.H.; Errington, M.L.; Lynch, M.A.; Bliss, T.V. Arachidonic acid induces a long-term activity-dependent enhancement of synaptic transmission in the hippocampus. Nature 1989, 341, 739-742. [CrossRef]

255. Fukaya, T.; Gondaira, T.; Kashiyae, Y.; Kotani, S.; Ishikura, Y.; Fujikawa, S.; Kiso, Y.; Sakakibara, M. Arachidonic acid preserves hippocampal neuron membrane fluidity in senescent rats. Neurobiol. Aging. 2007, 28, 1179-1186. [CrossRef]

256. Wang, Z.J.; Liang, C.L.; Li, G.M.; Yu, C.Y.; Yin, M. Neuroprotective effects of arachidonic acid against oxidative stress on rat hippocampal slices. Chem. Biol. Interact. 2006, 163, 207-217. [CrossRef]

257. Darios, F.; Davletov, B. Omega-3 and omega- 6 fatty acids stimulate cell membrane expansion by acting on syntaxin 3 . Nature 2006, 440, 813-817. [CrossRef] [PubMed]

258. Darios, F.; Ruiperez, V.; Lopez, I.; Villanueva, J.; Gutierrez, L.M.; Davletov, B. Alpha-synuclein sequesters arachidonic acid to modulate SNARE-mediated exocytosis. EMBO Rep. 2010, 11, 528-533. [CrossRef] [PubMed]

259. Yasojima, K.; Schwab, C.; McGeer, E.G.; McGeer, P.L. Distribution of cyclooxygenase-1 and cyclooxygenase-2 mRNAs and proteins in human brain and peripheral organs. Brain Res. 1999, 830, 226-236. [CrossRef] 
260. McGahon, B.; Clements, M.P.; Lynch, M.A. The ability of aged rats to sustain long-term potentiation is restored when the age-related decrease in membrane arachidonic acid concentration is reversed. Neuroscience 1997, 81, 9-16. [CrossRef]

261. Angelova, P.R.; Muller, W.S. Arachidonic acid potently inhibits both postsynaptic-type Kv4.2 and presynaptic-type Kv1.4 IA potassium channels. Eur. J. Neurosci. 2009, 29, 1943-1950. [CrossRef]

262. Connell, E.; Darios, F.; Broersen, K.; Gatsby, N.; Peak-Chew, S.Y.; Rickman, C.; Davletov, B. Mechanism of arachidonic acid action on syntaxin-Munc18. EMBO Rep. 2007, 8, 414-419. [CrossRef] [PubMed]

263. Boneva, N.B.; Kikuchi, M.; Minabe, Y.; Yamashima, T. Neuroprotective and ameliorative actions of polyunsaturated fatty acids against neuronal diseases: Implication of fatty acid-binding proteins (FABP) and G protein-coupled receptor 40 (GPR40) in adult neurogenesis. J. Pharmacol. Sci. 2011, 116, 163-172. [CrossRef] [PubMed]

264. Pan, Y.; Scanlon, M.J.; Owada, Y.; Yamamoto, Y.; Porter, C.J.; Nicolazzo, J.A. Fatty acid-binding protein 5 facilitates the blood-brain barrier transport of docosahexaenoic acid. Mol. Pharm. 2015, 12, 4375-4385. [CrossRef]

265. Marszalek, J.R.; Kitidis, C.; Dirusso, C.C.; Lodish, H.F. Long-chain acyl-CoA synthetase 6 preferentially promotes DHA metabolism. J. Biol. Chem. 2005, 280, 10817-10826. [CrossRef] [PubMed]

266. Green, J.T.; Orr, S.K.; Bazinet, R.P. The emerging role of group VI calcium-independent phospholipase A2 in releasing docosahexaenoic acid from brain phospholipids. J. Lipid Res. 2008, 49, 939-944. [CrossRef]

267. Martinez, M. Tissue levels of polyunsaturated fatty acids during early human development. J. Pediatr. 1992, 120, S129-S138. [CrossRef]

268. Bitsanis, D.; Crawford, M.A.; Moodley, T.; Holmsen, H.; Ghebremeskel, K.; Djahanbakhch, O. Arachidonic acid predominates in the membrane phosphoglycerides of the early and term human placenta. J. Nutr. 2005, 135, 2566-2571. [CrossRef]

269. Dutta-Roy, A.K.; Sinha, A.K. Purification and properties of prostaglandin E1/prostacyclin receptor of human blood platelets. J. Biol. Chem. 1987, 262, 12685-12691. [CrossRef]

270. Luo, C.L.; Li, Q.Q.; Chen, X.P.; Zhang, X.M.; Li, L.L.; Li, B.X.; Zhao, Z.Q.; Tao, L.Y. Lipoxin A4 attenuates brain damage and downregulates the production of pro-inflammatory cytokines and phosphorylated mitogen-activated protein kinases in a mouse model of traumatic brain injury. Brain Res. 2013, 1502, 1-10. [CrossRef]

271. Pamplona, F.A.; Ferreira, J.; Menezes de Lima, O., Jr.; Duarte, F.S.; Bento, A.F.; Forner, S.; Villarinho, J.G.; Bellocchio, L.; Wotjak, C.T.; Lerner, R.; et al. Anti-inflammatory lipoxin A4 is an endogenous allosteric enhancer of CB1 cannabinoid receptor. Proc. Natl. Acad. Sci. USA 2012, 109, 21134-21139. [CrossRef]

272. Qawasmi, A.; Landeros-Weisenberger, A.; Leckman, J.F.; Bloch, M.H. Meta-analysis of long-chain polyunsaturated fatty acid supplementation of formula and infant cognition. Pediatrics 2012. [CrossRef] [PubMed]

273. Simmer, K.; Patole, S.K.; Rao, S.C. Long-chain polyunsaturated fatty acid supplementation in infants born at term. Cochrane Database Syst. Rev. 2011. [CrossRef]

274. Smithers, L.G.; Gibson, R.A.; McPhee, A.; Makrides, M. Effect of long-chain polyunsaturated fatty acid supplementation of preterm infants on disease risk and neurodevelopment: A systematic review of randomized controlled trials. Am. J. Clin. Nutr. 2008, 87, 912-920. [CrossRef]

275. Lauritzen, L.; Fewtrell, M.; Agostoni, C. Dietary arachidonic acid in perinatal nutrition: A commentary. Pediatr. Res. 2015, 77, 263-269. [CrossRef]

276. Alshweki, A.; Muñuzuri, A.P.; Baña, A.M.; de Castro, M.J.; Andrade, F.; Aldamiz-Echevarría, L.; de Pipaón, M.S.; Fraga, J.M.; Couce, M.L. Effects of different arachidonic acid supplementation on psychomotor development in very preterm infants; a randomized controlled trial. Nutr. J. 2015, 14, 101. [CrossRef] [PubMed]

277. Crawford, M.A.; Costeloe, K.; Ghebremeskel, K.; Phylactos, A.; Skirvin, L.; Stacey, F. Are deficits of arachidonic and docosahexaenoic acids responsible for the neural and vascular complications of preterm babies? Am. J. Clin. Nutr. 1997, 66, 1032S-S1041S. [CrossRef] [PubMed]

278. Forsyth, S.; Calder, P.C.; Zotor, F.; Amuna, P.; Meyer, B.; Holub, B. Dietary Docosahexaenoic Acid and Arachidonic Acid in Early Life: What Is the Best Evidence for Policymakers? Ann. Nutr. Metab. 2018, 72, 210-222. [CrossRef] [PubMed] 